\title{
De gallo peregrino, the wandering cock
}

Meleagris gallopavo L. 1758 in western Europe, through old texts $\left(15^{\text {th }}-18^{\text {th }}\right.$ centuries $)$

\section{Serge Bahuchet}

Translator. Mathilde Bognon

\section{Q OpenEdition \\ Journals}

\section{Electronic version}

URL: https://journals.openedition.org/ethnoecologie/6897

DOI: 10.4000/ethnoecologie.6897

ISSN: 2267-2419

\section{Publisher}

Laboratoire Éco-anthropologie

\section{Electronic reference}

Serge Bahuchet, "De gallo peregrino, the wandering cock", Revue d'ethnoécologie [Online], 19| 2021,

Online since 10 June 2021, connection on 17 December 2021. URL: http://journals.openedition.org/ ethnoecologie/6897; DOI: https://doi.org/10.4000/ethnoecologie.6897

This text was automatically generated on 17 December 2021.

\section{cc) (†)}

Revue d'ethnoécologie est mis à disposition selon les termes de la licence Creative Commons Attribution - Pas d'Utilisation Commerciale - Pas de Modification 4.0 International. 


\section{De gallo peregrino, the wandering cock}

Meleagris gallopavo L. 1758 in western Europe, through old texts ( $15^{\text {th }}-18^{\text {th }}$ centuries)

\section{Serge Bahuchet}

Translation : Mathilde Bognon

\section{EDITOR'S NOTE}

La traduction de ce texte est de Mathilde Bognon

\section{Introduction}

1 America has provided Europe with the main food plants, several of which have been adopted immediately after they were discovered (corn, squash, beans, chilli peppers). Among the five animals domesticated by the Native Americans, three were quickly brought to Europe: Muscovy ducks, guinea pigs and turkeys. Both camelids, llamas and alpacas, did not meet a major destiny outside their original continent ( $c f$. Geoffroy Saint-Hilaire 1861 : 26-27, Bahuchet 2017).

2 Of the two birds, the Muscovy duck quickly blended into the barnyard, to the point where it did not leave an actual trace in the written works of that time. The other one, the turkey, is really the only American animal to have taken on such an important universal economic and alimentary importance. How did this borrowing from the Ancient to the New World occur?

In this article, we will examine the conditions and consequences of the discovery of the turkey Meleagris gallopavo L. (Phasianideae). I will try to grasp how this new animal has established itself in the languages, through terminology, in scientific knowledge and in the customs and practices in view to specify the steps of its acceptance and inclusion in the European alimentary corpus. This investigation will be conducted through the 
chronological analysis of the successive written testimonies, that is to say the archives which have been revealed by historians, and mostly the books, in order to evidence the steps of the adoption of the turkey in our European civilization.

\section{Well-documented sources}

4 Several publications have thoroughly scrutinized the historical sources concerning the introduction of the turkey in Europe, providing a practically complete base upon which all new researches are leaning, and to which it is pointless to hope to add anything new, except through deeper researches into the archives. The primer on which all later publications are based is Schorger 1966 (preceded by the pioneering and well-informed article by Wright in 1914) and completed by the richly illustrated book by Eiche 2004 . Flandrin 1992 and then Plouvier 1995 have studied the place of the turkey in cookbooks, and Poplin 1992 introduced the turkey in our bestiary. More recently, Boudier 2009, Orlandi 2011, De Grossi Mazzorin \& Epifani 2016 have brought new historical documents to the ones that had already been published.

5 For this chapter, I went from the sources that had been previously discovered by prior authors, coming back to the original texts as much as possible. I have thereby rallied multiple types of sources in order to have different types of information that complete one another - historical accounts, cookbooks and health books, monolingual and multilingual dictionaries, agricultural and home economics books, from the four Mediterranean countries, Spain, Portugal, France and Italy, and from England. Unless otherwise stated, I carried out myself the translations, with the original texts quoted in footnotes.

6 I restricted myself to historical sources, publications and archives, and I knowingly left out ongoing archaelogical and archaeozoological studies, which are the focus of a synthetical book in preparation (Exploring the history of the turkey domestication and management, edited by A. Manin, C. Speller, E. Corona \& E. Thornton, publications scientifiques du MNHN).

7 About the discovery and introduction of the turkey in Europe, there has not been any new document to change the already well-known picture, which has reached a sort of consensus. We now know the great stages; all we may expect are clarifications and specifications about the details. The goal of this chapter is to summarise the state of knowledge about the introduction of the turkey in Europe, while trying to bring some new information from the documents of the time, in view to grasp the place that this bird has taken up in the European agriculture and diet.

8 I will distinguish several steps, for which I will gather as many contemporary testimonies as possible: who discovered the turkey, this new type of poultry? How was it introduced in Spain, and from there, how did it spread throughout Europe? How did it move from the royal aviaries and noble tables to barnyards? How were the initial difficulties to raise it overcome, and where do turkeys belong in our kitchens?

\section{Reminder of the historical context}

9 The discovery and introduction of the turkey in Europe sets in a particularly complex and dramatic geopolitical context, with regard to the relations among European countries, a time when the organisation of the world changed significantly. 
Unfortunately, there is no evidence of Columbus bringing turkeys back to Seville after this dramatic voyage; quite the contrary, even, since he had been captured by his successor and was coming back to Spain as a prisoner.

The first voyage to have reached the coast of Venezuela is the voyage of Pedro Alonso Nuñez, or Niño, in 1499-1500 (cf. Orlandi 2011: 77). His group was in prolonged contact with the Indians in Curiana, as described by Peter Martyr:

"The women keep ducks and geese about the houses, just as ours do; peacocks fly about in the woods, but their colours are not so rich or so varied as ours and the male bird differs little from the female. (...) The Spaniards spent several days amongst the abundance of the country. They traded four needles for a peacock, only two for a pheasant, and one for a dove or a turtle-dove." (De Orbe Novo, First decade, Book VIII, transl. MacNutt, p. 152) ${ }^{7}$

However it is possible that these birds belong to another wild species, Meleagris ocellata, endemic to Yucatan and Guatemala (A. Manin, comm. pers., cf. Manin et al. 2018).

said that "The Spaniards brought away some very pretty monkeys and a number of parrots of varied colours, from that country" (p. 154) ${ }^{8}$, but mostly a great quantity of pearls "Many of these stones (...) as large as nuts" (p. 157) (which Martyr was able to see) - for which Nuñez was imprisoned upon his arrival in Pontevedra, Galicia, for hiding some of it! Unfortunately, there is no mention of "peafowls" brought back to Spain by this expedition, though it is possible that they have been.

50 years later, Spanish navigators Victor Yañez Pinzon and Juan Diaz de Solis travelled along the coast of central America, from Honduras to Yucatan, between 1508 and $1509^{9}$. During this voyage, they saw "peafowls", about which Peter Martyr talks, in the context of a difficult contact between the Spanish and the natives; the caciques feared that their villages might be pillaged, so they asked for peace and sent ambassadors with presents to Vincent Yañez:

"In addition to the gold and the incense, they presented peacocks such as are not found elsewhere, for they differ largely from ours in the variety of their colours. The hens were alive, for they kept them to propagate the species, but the cocks, which they brought in great numbers, were dressed to be immediately eaten." (tr. MacNut, 1912, vol. 1, Second Decad, Book VII, p. 254)

20 It is this text that seems to be considered as proof of Yañez transporting turkeys towards Spain ( $c f$. Wright 1914) but, though it is possible, its interpretation is debatable, judging by the modern translations ${ }^{10}$.

\section{What is that bird?}

21 The encounter with the turkey leads to a confrontation with something hitherto unseen. To describe it, observers compare its morphology with what they know from Europe. This bird could look like a chicken, but it is enormous, and looks like a peafowl, because males fan their tails. In his Somario de la natural y general historia de las Indias in 1526, Gonzalo Fernandez de Oviedo gives a first local naturalistic description and endeavours to describe and contrast Indian peafowls with Spanish peafowls lengthily, in favour of the new bird:

"There are some peafowls reddish (ruby) and others black, and the tails have the shape of the peahens of Spain; but in plumage and in color, some are entirely reddish (ruby), and the abdomen with a little of the breast white, and the others entirely black, and in the same manner the abdomen and part of the breast white; 
and both have upon the head a beautiful crest or tuft, of red feathers for the red ones, and black for the black ones, and they are better to eat than those of Spain. These peafowls are wild, and some are domesticated in the houses when they are taken young. The archers kill many of them because they are in great number. (...)" (Somario ..., 1526, Pavos, Cap. Xxxvij; transl. by A.J. Lamoureux, in Wright 1914: 350) ${ }^{11}$

Note that the turkey is half wild half domesticated, which leads us to think that they were free range farmed, in large quantities ${ }^{12}$. Oviedo then lingers over comparing its plumage, its bare head and mostly its tail. As a conclusion, he comes back on its gustatory quality: "The meat of these peafowls is very good, and incomparably better and more tender than that of the peafowl of Spain" (Somario... 1526) ${ }^{13}$.

Soon after, Italian cook Bartolomeo Scappi will also compare the turkey and the peafowl in those words:

"The Indian cocks and hens have much bigger bodies than our peafowls, and cocks fan their tails just like peacocks, and have black and white feathers; their necks are hairless, and their heads carry fleshy horns which, when they become irritated, swell and become so big that they cover their entire moustache; (...) on the chest, among the feathers, they have bristles, like pigs do; their flesh is way whiter and softer than our peafowls' and they tenderise quicker than capons' or other similar type of poultry's's." (Scappi 1570, ch 141; our tr.)

In those same years, the first zoological descriptions will stumble over several difficulties: first, how to describe something that has never been seen before, that is to say what shall it be compared to? Then, what to name it and how to include it in the field of the known - meaning confronting it with classical texts from Ancient authors.

The naturalists of the $16^{\text {th }}$ and then the $17^{\text {th }}$ centuries indicate the difficulty to confront ancient Antiquity texts with the objective observations they make about them. Science at this time was based on analyses, commentaries and exegeses of texts from Antiquity scholars (Varro, Columella, Pliny...). We see it in botanists' publications who try to define which plants have been described by Theophrastus or Dioscorides, and also in zoology books.

Concerning the turkey, the engravings prove that the authors (or their illustrators) know the bird and have seen it. As is illustrated by some incidental sentences, for instance with Gessner: "Of the wandering cock: The one that I saw which came from the new world..." and later on "The one that I saw... ${ }^{15 "}$. The first engraving, which is excellent, is the one published by Conrad Gessner in 1553 (Icones avium omnium p. 56) and then repeated in 1555 (Historiae animalium Liber III qui est de Avium natura pp. 464-465) [Figure 1]. That same year, Pierre Belon illustrated the turkey (De l'histoire de la nature des oiseaux pp. 148-149) [Figure 2]. And yet the texts by these authors are very disappointing in their imprecision, and in the few information they bring about the animal. They all quote great reference authors, and then get mixed up, talking about Latin texts to confirm or contest whether these ancients have known the bird or not. There is a complete confusion with the guineafow ${ }^{16}$, through its ancient Greek name Meleagris, and the confusion is augmented by the name "Indian" given by the explorers to the Antillean Islands and then to the continent, and hence to the bird, the Indian cock and hen. 
Figure 1: The gallopavo of Conrad Gessner in 1553 (Icones avium omnium)

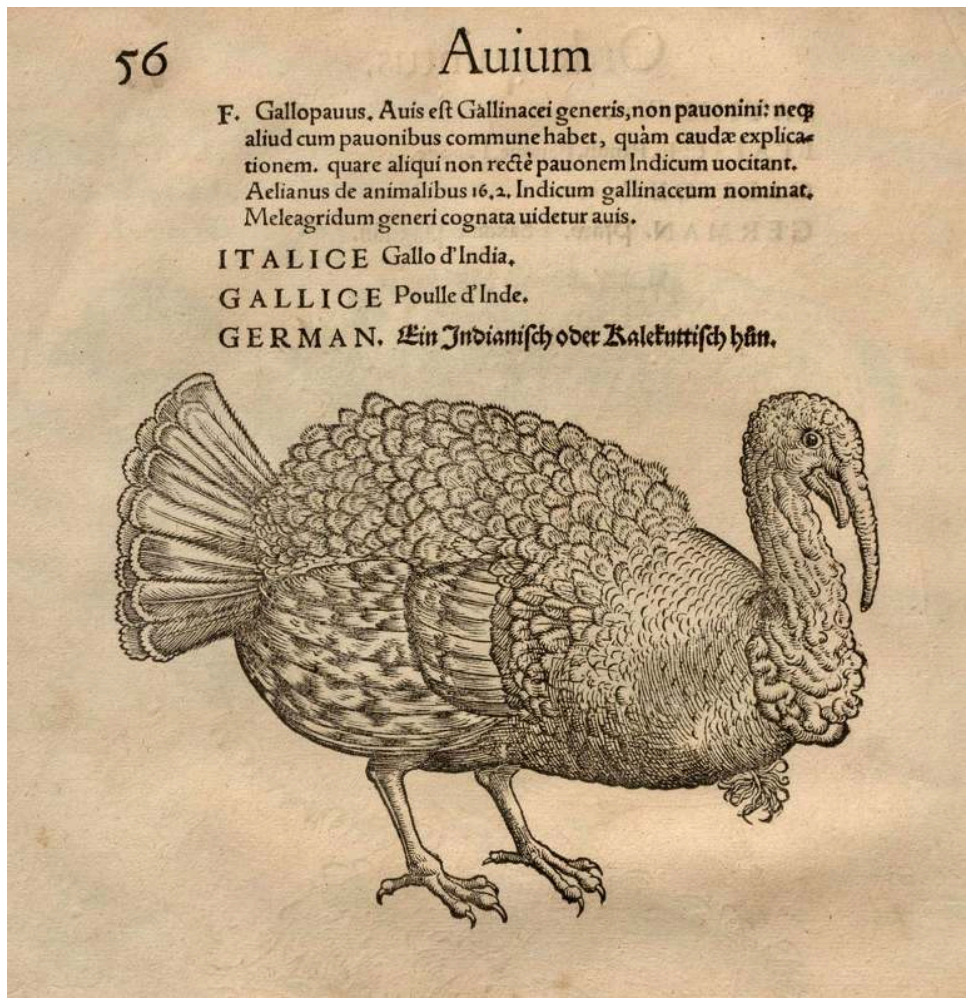

Figure 2: The coc d'Inde of Pierre Belon, De I'histoire de la nature des oiseaux avec leurs descriptions et naïfs portraicts (1555)

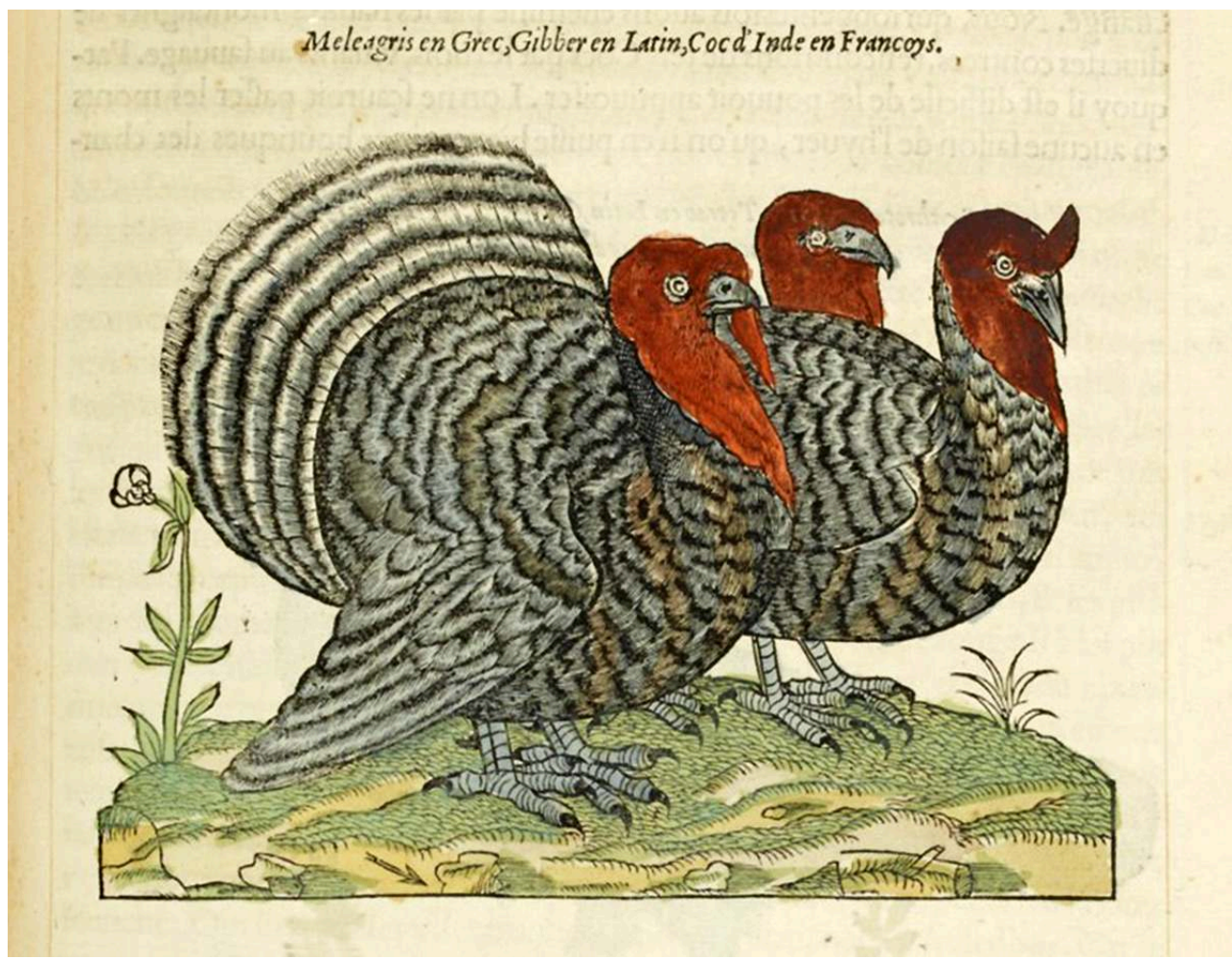

27 A little while later, in 1600, naturalist Ulisse Aldrovandi in his second ornithology volume, drew very realistically both the male (Gallopavo) and female (Gallina Indica) ${ }^{17}$ 
[Figure 3]. Further in the book, in the section about hens, he represented an imaginative shape, we might almost say mythical, of Gallus indicus auratus tridactylus, which has often been reproduced (p. 330-331) ${ }^{18}$. However, nothing in the description associated to this plate suggests any type of parallel with the Gallopavo (p. 35).

Figure 3: The gallopavo in Ornithologiae of Ulisse Aldrovandi (1600)

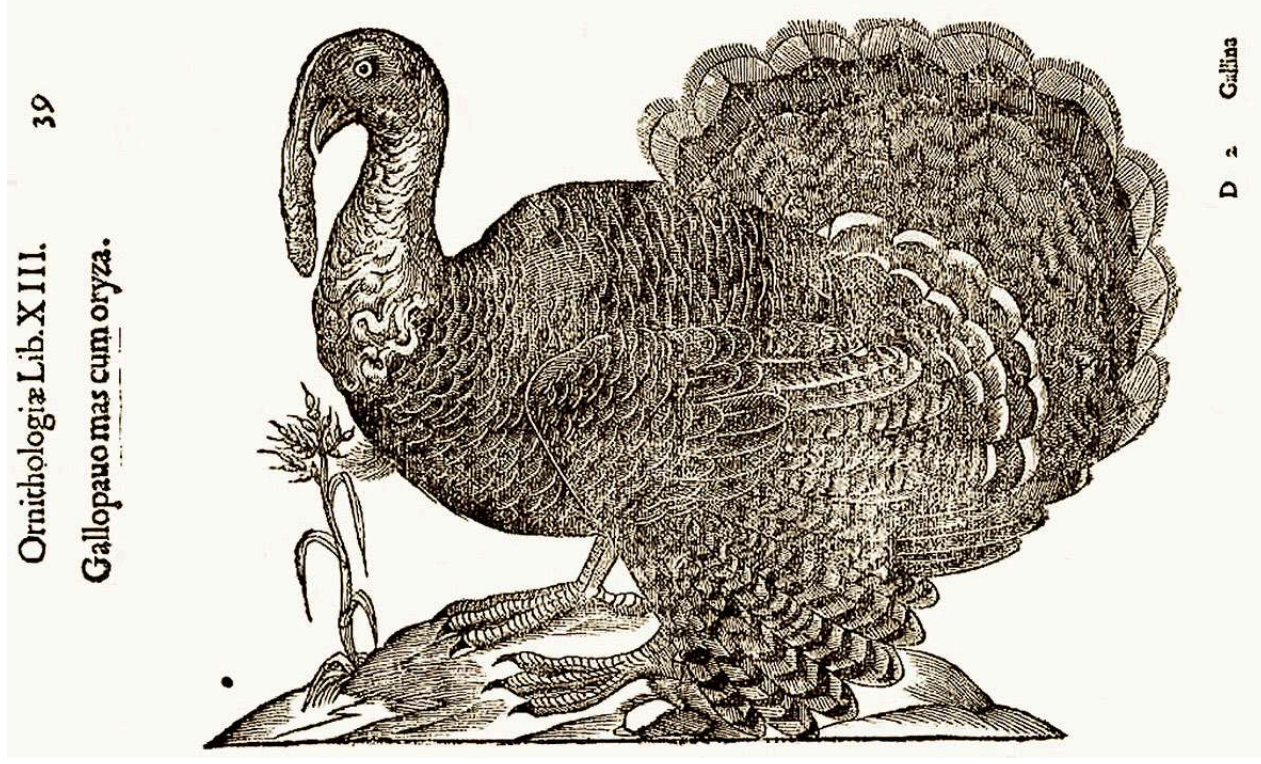

The discovery of the New World with its unknown flora and more importantly fauna having nothing to do with the Mediterranean's, has posed problems to naturalists and ended up, a century later, helping them move away from ancient science. The considerations of father José de Acosta who stayed in South America in the $16^{\text {th }}$ century (Historia natural y moral de las Indias, The Natural and moral history of the Indies, 1590) are enlightening, though he did not see any turkey. He wondered about the fauna he found in Peru and which was nowhere else in the world (i.e. in Europe): who brought them to Peru, or how did they get there? (ed. 1880: 277). In a word: do they also come from Noah's Ark? He then spread his thoughts to African and Asian animals, which were unknown in Europe,

"of a thousand different kindes of birdes and beasts of the forrest, which have never beene knowne, neither in shape nor name; and whereof there is no mention made, -neither among the Latins nor Greekes, nor any other nations of the world." (tr. E. Grimston 1604, éd. $1880: 277)^{19}$

An extreme and belated though insightful example is that of John Johnston in article II of his Historiae naturalis de avibus where he talks about «Pavone albo, pavonibus Iaponensis \& gallopavone" (p.39), and also refers to classical authors, Varro, Pliny, Diodorus, Theophrastus, Gallienus, Strabo, Columella, etc. But his illustrations are quite puzzling: plate 24 represents a beautiful turkey cock and turkey hen, very realistic (the caption "Gallopavus mas cum Orÿzae" allows us to credit them to Aldrovandi without a doubt), on the same plate, a guineafowl (Gallina Africanae). Plate 29 represents a "Gallus indicus, Welscher han", a beautiful white turkey cock fanning its tails (though without a wattle), among many different races of cocks (including a horned cock...); plate 30, also among many different races of cocks, presents the Gallus indicus mirabilis, this sort of 
miraculous bird presented in Aldrovrandi, next to a guineafowl Gallina Guinea, much more realistic than the one in plate 24 , with its characteristic helmeted crest.

This lingering confusion is found occasionally in cookbooks, for instance in the Italian book of Baldassare Pisanelli Trattato della natura de cibi e del bere (1583), where the part about the gallo d'India quite specifically refers to the guineafowl, and not the turkey (see below).

\section{How to name this new type of poultry?}

What are the ancient and current terms, and when were they coined? I have looked at when they have appeared in books with the modern meaning of "turkey", as opposed to similar already known birds such as peafowls and guineafowls. (Table 2 and 3 ).

Table 2: Ancient names (according to dictionaries and cookbooks)

\begin{tabular}{|c|c|c|c|c|}
\hline Signification & French & Spanish & Italian & Portuguese \\
\hline Male & Coq d'Inde, coq-dinde & $\begin{array}{c}\text { Gallipavo, pavo de India, } \\
\text { gallo de las Indias }\end{array}$ & $\begin{array}{c}\text { Pavo de Indias, gallipavo, } \\
\text { gallo d'India, gallinaccio }\end{array}$ & Perù \\
\hline Female & $\begin{array}{c}\text { Poule d'Inde, poulle d'Inde, } \\
\text { poule-dinde, dinde }\end{array}$ & $\begin{array}{c}\text { Polla de Indias, gallina de la Indias, } \\
\text { pava }\end{array}$ & Gallina d'India, pollanche d'India & Perua \\
\hline Chicks & $\begin{array}{c}\text { Poulet d'Inde, poulet-dinde, } \\
\text { dindon, dindonneau }\end{array}$ & Pavipollos, pavillos & Pollastre & \\
\hline Peacock & Paon & Pavo, pavón & Pavone, paone & Pavão \\
\hline
\end{tabular}

Table 3: Names in current languages

\begin{tabular}{c|c|c|c|c|}
\hline French & Spanish & Italian & Portuguese & English \\
\hline Dinde, dindon & pava, pavo & tacchina, tacchino & Perua, peru & turkey \\
\hline Pintade & pintada & gallina faraona & pintada, galinha da Índia & guinea-fowl \\
\hline Paon & pavo real & pavone & pavão & peacock \\
\hline
\end{tabular}

In Spanish dictionaries, the original meaning of pavo is "Peafowl", and its assignation to "Turkey" was not set until the beginning of the $17^{\text {th }}$ century:

- 1495, Antonio de Nebrija Dictionarium latinohispanicum: «Pavo o pava o pavon. Pauus.i.pavo.onis »

- 1570, Cristóbal de las Casas Vocabolario de las dos lenguas toscana y castellana: « Gallina. gallina. Pauone. pauon "

- 1591, Richard Percival A Dictionarie in Spanish and English, and Latine: «Pavo, pava y pavon, a peacock, Pavo. "

That is when the difference between "turkey" and "peafowl" became official:

- 1611, Sebastián de Covarrubias, Tesoro de la lengua castellana: "Pavo, que por otro nombre le llama gallo de las Indias. Pavon, por otro nombre pauo real [...]» ("Pavo, which is also named gallo de las Indias. Pavon, another name pauo real.")

- 1617, John Minsheu A Dictionnary in Spanish and English: «Pávo, o pavón. L. pávo. A. a peacock. Pavón de las Indias. L. Gallo-pavo. A. a Turkie-cock. ${ }^{20}$

- 1675, Caesar Oudin Thresor des deux langues françoise et espagnolle: «Gallipavo, coq d'Inde ; Pavo de India, coq d'Inde. »

- 1737, Diccionario de la lengua castellana: " ${ }_{\text {pavo }}$. Ave domestica, mucho mejor que la gallina. Lat. Gallus Indicus. [...]. Pavon. La mas hermosa de las aves [...]. Llámase tambien Pavo real. Lat. Pavo. [...]» (" ${ }_{\text {Pavo }}$. A domestic bird, much better that the chicken. Lat. 
Gallus Indicus. [...]. Pavon . The must beautiful of all birds. [...]. Also cold Pavo real. Lat. Pavo. [...]»).

To recap, when they landed in Central America, the Spanish found big domesticated birds (Meleagris gallopavo L.) which they hesitated to call gallina (hen) or pavo (peafowl). When they definitely decided on pavo, the true Peafowl (Pavo cristatus) from Eurasia and bred in Europe since the Antiquity became the pavo real ("royal peafowl") or pavón ("great peafowl").

In Italian, in the $16^{\text {th }}$ century, cooks used the word Gallina d'India (for instance Romoli 1560, Scappi 1570), and sometimes joined the word Pavone when the peafowl was also in the recipe (for instance in Messisbugo 1549, Cervio 1593).

The phrase gallina d'India is used throughout the whole $17^{\text {th }}$ century, with variations (gallinaccio, gallo d'India, gallipavo ${ }^{21}$ ):

- 1603, Pierre Canal Dictionnaire français-italien: « Poule d'Inde, Gallina d'India »

- 1627, Caesar Oudin Thresor des trois langues: «Poulle ou coq d'Inde ; gallo d'India, gallipavo ; pavo de Indias, gallipavo "

- 1752, Annibal Antonini Dictionnaire italien-français: «Gallinaccio. Dindon, coq d'Inde. »

unexpected variant:

- 1678, Nathanaël Düez Dictionnaire italien-français: «Gallina gobba. Poulle d'Inde ». [Gobba: hunchbacked].

- 1691, Oudin, achevé par Veneroni : «Gallina gobba, Poule d'Inde. Gallina rusticilla, Poule d'Inde. Gallinaccio, Poulet d'Inde. »

From then on, dictionaries used this word to designate the turkey, with or without the reference to the name gallo d'India. In 1674 Tanara wrote:

"this animal does not have a defined name yet; some call it Gallo d'India, others Pavo

Gallo, others Gallo Pavone, and others yet Gallinazzio, and farmers call it Tocco ${ }^{22 "}$.

The 1829 Vocabolario universal italiano, from the Typographic society, gives a very interesting explanation:

"Tacchino. A kind of gallinacean bird which has red and blue head, with some rare

hair. (...) also Pollino, Pollo d'India, and more generally Gallo d'India, Gallonaccio. (...)

Tacchino differs from Pollo d'India, which is from noble Italian language, while

Tacchino is from Toscana language." ${ }^{23}$ (our tr.).

The etymology of Tacchino is unknown. Some articles consider tocco as an onomatopoeia at the origin of tacchino (a strange onomatopoeia for a bird that gobbles). But etymological dictionaries indicate that they don't know and suggest, with no real conviction, a possible reference to tacca for the feathers' markings (...), or even to the Turkish word tang "hen" (...)!

Be that as it may, the word tacchino imposed itself definitely in the $19^{\text {th }}$ century.

In France, "dinde" is an elision of "poule d'Inde" (Indian hen), a term which predominated until the middle of the $17^{\text {th }}$ century, with strong fluctuations due to the search for clarifications concerning the bird's growth stages and to the uncertainty of the spelling at that time. We go from "coc d'Inde" or "poulle d'Inde" to just "d'Inde" and quickly Dinde. Olivier de Serres (1600) gave us an example using all the possible forms: the poulaille d'inde, the poule d'inde, the poules d'indes, the d'indes, the dinde, the coqs d'inde, the d'indard, the d'indards, the d'indons, the petits d'indons, the dindons. 
- This term is not in the first edition of Trévoux (1738-1742, still "coq d'Inde", Dictionnaire universel françois et latin); but "Dindes" and "Poules d'inde" appear in Noël Chomel's Ecumenical Dictionary (1741), and in the Encyclopedia (volume IV, 1754): "Dinde: Coq d'Inde. Dindon: young coq d'Inde. Dindonneau: is a young dindon, when it is still no bigger than a fist." Similarly, in the $4^{\text {th }}$ edition of the Dictionnaire de l'Académie (1762): "Dindon, coq d'Inde" and in the $6^{\text {th }}$ edition of Trévoux in 1771: "Dinde: Coq d'Inde. We also sometimes call it poule d'Inde. Dindon: coq d'Inde. ${ }^{26 "}$

- In 1771 also, Buffon describes "le Dindon" in Volume II of his Histoire naturelle des Oiseaux [Figure 4]. 
Figure 4: "Dindon and dinde in the barnyard"; Buffon, Histoire naturelle des oiseaux, T. II, 1771

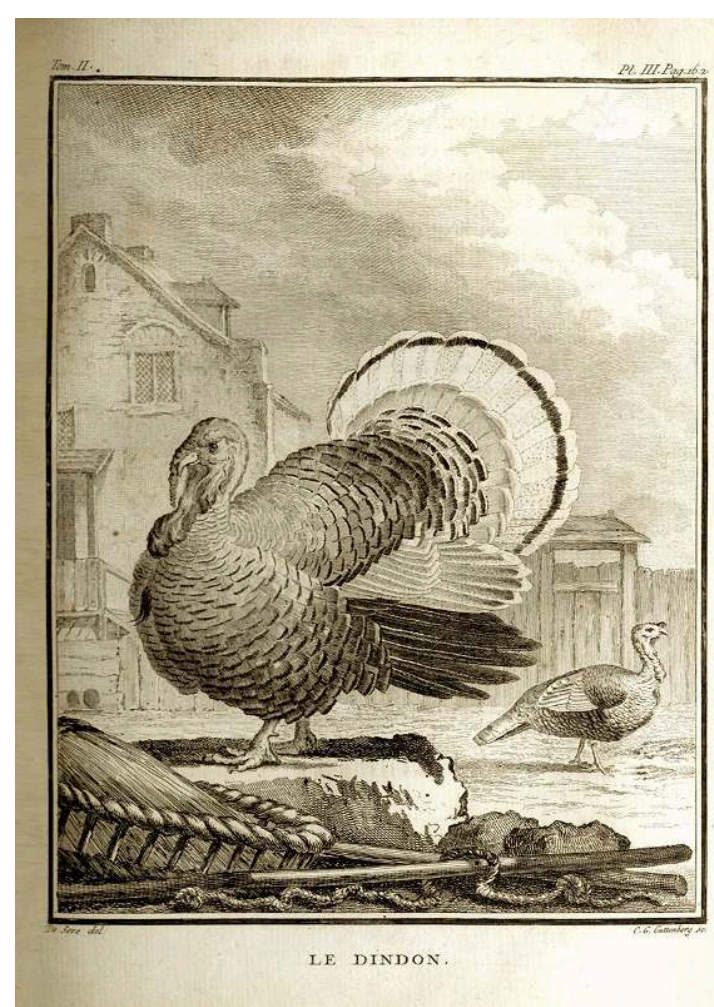

The word "dinde" is initially both masculine and feminine and can describe the Indian cock and hen. The use of "dindon" for the male, and not for the young ones, gradually emerged:

- Féraud, Dictionnaire critique de la langue française (1787-1788): “Dinde: So is sometimes called the poule d'inde (Indian hen). Dindon, Coq-d'inde (Indian cock). ${ }^{27 "}$

- It is only in the $6^{\text {th }}$ edition of the Dictionnaire de l'Académie (1832) that there is no reference to Coq d'Inde: "DINDON. Large farmyard bird whose flesh is much prized.". However in the 1835 edition, the explanation gives again: "DINDE. Female of dindon, also named Poule d'Inde ${ }^{28}$."

In Portuguese, it seems that the American bird has been immediately named with a proper noun, perú, the same name that was used to call South America, with no reference to the Eurasian peafowl (pavão), and probably as an elision to the "Peruvian hens" (Gallinha do Perú), just like the other Latin languages referred to India ("poule des Indes"):

- 1728, Raphael Bluteau Vocabulario portuguez e latino: "Perû. A domestic bird (...), in Italy is named, Gallo Indiano, \& Gallo d'India ; in France Coqdinde; in Spain, Pavo, or Gallo de las Indias. (...) [latin] Gallus Indicus." ${ }^{29}$

- 1789, Antonio de Moraes Silva Diccionario da lingua portugueza: " feathered bird, domestic. Vulgarly sayed perum: they are called Peru, because of the vice-kingdom of Peru, and at the beginning they were called Poules $d u$ Pérou. $»^{30}$

In English, our bird was immediately called Turkey, with various written forms, generally prolonged with kok, cock, fowles. The comparison with other languages confirms its meaning:

- 1584, A. W. A Book of Cookrye: "Turky Fowles"

- 1611, Randle Cotgrave A dictionarie of the French and English tongues : «Dindar. A Turkie- 
cocke; Seeke Indar. (...) Indar. A Turkie Cocke. (...) (s.v. Inde) D’Inde. A Turkie Henne. Coq d'Inde. A Turkie Cocke. ${ }^{31}$

The oddness of this bird and its unknown origin are marked by an exotic geographic name which is usually appended to "coq" or "poule": Inde (India) in Spanish, French and Italian, Peru (Perú) in Portuguese, Turkey in English, Calicut (after a port in the south of India) for German ${ }^{32}$, without it necessarily indicating a specific location.

\section{When did the first turkey arrive in europe?}

51 The most important document, which was often quoted ${ }^{33}$, and the most ancient to this day, is the royal letter sent from Burgos on 24 October 1511 addressed to Miguel de Pasamonte, chief treasurer of the Indies), and summed up as follows in the General Archives of the Indies:

Miguel de Pasamonte, our chief treasurer of the Islands and Tierra Firme: "I order you that in each of those ships that come here (...) you bring us well guarded ten turkeys, half males, half females, and have them given to our officials of the Casa de la Contratación, in Seville, that they keep them to whatever purpose we order." (trad. in Schorger $1966: 464)^{34}$

This is therefore the terminus ante quem, since the date indicates that the turkey has to have appeared before 1511. And this requirement indicates that it was already considered useful, or even precious, and possibly farmable ${ }^{35}$.

It is important to remind that though turkeys were farmed animals in Mexico, which is the probable source of domestication ${ }^{36}$, Cortès did not reach this region and Mexico city until 151937: so the encounter with this bird in Central America (Venezuela, Honduras, Yucatan) and its introduction to Spain before 1511 are anterior to the conquest of Mexico.

What are the first historical testimonies certifying the presence of turkeys in various countries? I present here the dates of the first texts that I know of, in various European countries $^{38}$.

- 1511 - Spain: royal requisition to the chief treasurer of the Indies.

- 1520 - Italy: Bishop of S Domingo, Alessandro Gerladini, sends a turkey and a white turkey to Cardinal Lorenzo Pucci in Rome for his aviary. (A testimony of the place of the turkey in royal gardens) (Eiche 2004: 22; Boudier 2009: 82). ${ }^{39}$

- 1534 - France: Marguerite of Angoulême, Queen of Navarre, owns turkeys in the park of her castle in Alençon. (Is it the proof of the introduction of turkeys in France through Navarre?).

- 1541 - England: Archbishop Thomas Cranmer commands the clergy to control their consumption of poultry (including turkeycocke) and big fish. (So turkeys were already widely spread, reproduced and consumed to the point where it could be too much so).

- 1557 - Belgium: pouilles and coqs d'Inde are served during a banquet in Liège (Lancelot de Casteau Ouverture de cuisine, 1604).

- 1560 - Germany, Arnstad: 150 turkeys are served at a wedding banquet (Schorger 1966: 471).

- 1570 - Germany: Conrad Heresbach Rei Rusticae Libri quatuor (adaptation of the Latin agriculture books), includes a section about "birds from the Indies": 
"These birds from the Indies quite recently appeared: it was not until 1530 in the year of our Lord that we have first seen them, no more than the ancient authors who suggested to call them Melegrides." ${ }^{40}$ (Our tr.) date of 1524 or 1525 for the direct introduction of turkeys without going through Spain, by a sailor of Sebastien Cabot's crew, William Strickland of Boyton Yorkshire ( $c f$. Eche 2004: 17-18). Another tradition suggests the importation of turkeys by Turkish merchants from Seville (Orlandi 2011: 78). But no text seems to confirm or document it specifically.

\section{What are the functions of the turkeys?}

\section{Odd birds, perfect for noble aviaries, gardens and farms}

All the first testimonies certify the interest of noblemen for this remarkable bird, which they all add to their living collection in their aviaries and parks (Boudier 2009).

- 1520 - Italy: I have already mentioned the delivery of a couple of turkeys to Cardinal Pucci in Rome "for the cock to be an illustration of the wonderful work of nature" ${ }^{41}$ for his aviary.

- 1531 - Italy: Giovanmaria della Porta receives two turkeys from Cardinal Salviati for the gardens of the Duke of Urbino ("knowing how much Your Lordship takes pleasure in new animals...", Eiche 2004: 22)

- 1534 - France, Alençon: Marguerite of Angoulême ${ }^{42}$, Queen of Navarre, leased the park of the castle of Alençon and tasks the farmer to take care of her turkeys (Odolant- 
Desnos 1787: 562).

- 1539 - France, Alençon: Jeanne, princess of Navarre, daughter of Queen Marguerite, left Alençon to continue her education in Plessis-lez-Tours and "left six poules d'indes, the first ones that appeared in France." ${ }^{43}$

- 1559 - La Hague, sieur de Gouberville: Wednesday 27 December 1559: "A servant of Malin Lucas, of Sainte Croyx à la Hague, brought me a cock and a hen turkey, I gave him 4 sols." ${ }^{4}$

1556 - a gift worthy of kings:

"With us, we made the greatest of them; \& we even valued them enough to be offered to the Kings as a gift worthy of them. When Charles IX passed through Amiens in 1566, among the gifts that the Corps-de-ville came to put at his feet, there were twelve turkeys." ${ }^{45}$ (Le Grand d'Aussy 1782 : 292, our tr.).

\section{A choice dish for noble feasts}

ere are countless testimonies about the luxury quality of this still expansive poultry. Geofroy Linocier claims "It is delicious food, worthy of a Lord's dinner table." (1583, L'histoire des plantes...), or Thresor de santé "We usually serve them at the table of men of means." (1607). In Italy, Stefani says that little turkeys are very tender in the summer and "highly appreciated at the table of the greatest lords (Signori grandi)" (1662).

Let us give some of the dates of the oldest events during which turkeys have been served:

- 1546 - December, Rouen: “wonderful banquet" offered by Baptiste Le Chandelier (c. 1490-1549), Counsellor at the Rouen Parliament and Prince of the fellowship of the Palinods, after his last year of service. He described it in a great poem in Latin, Parthenia. In this three-service banquet with over 80 dishes, three poules d'Inde ${ }^{46}$ dishes were served (Bouquet 1883). (It seems to have been the first occurrence of turkey in a French feast).

- 1549 - 19 June, Paris: banquet offered by Catherine de' Medici for the diocese of Paris, during which 66 turkeys and 40 pâtés made of 5 turkeys ${ }^{47}$ were served.

- 1555 - 16 October, London: Turkies ${ }^{48}$ are served at the newly elected Serjeants-at-Law dinner, where each new member contributed to the banquet.

- 1557 - December, Liège: pouilles and coqs d'Inde are served during a banquet for Robert de Bergues, Bishop and Prince of Liège (Lancelot de Casteau Ouverture de cuisine, 1604).

- 1565 - 5 December, Brussels: banquet for the wedding of Alexander Farnese and Maria of Portugal (Eiche pp. 41-43: two engravings illustrate the flock of servants carrying turkey and peacock pâtés).

- 1570 - 26 November, banquet for the wedding of Charles IX ${ }^{49}$.

- 1581 - May, Mantua: during a royal banquet for the wedding of the Prince of Mantua, roasted or braised Pollanche d'India are served (Vincenzio Cervio II trinciante 1593).

- 1610 - January, Rome: banquet offered by Cardinal Aldobrandino, Camerlengo of the Santa Chiesa a tutti li monsignori auditori di Rota (members of the tribunal of the Holy See), with turkey pâtés ${ }^{50}$ served cold and roasts; similarly in February, a banquet offered to the ambassador of France ${ }^{51}$ (Vittorio Lancellotti Lo scalco pratico, 1627). 


\section{Too much ostentation?}

64 known, which explicitly mention turkey, one in England, of religious origin, and the other in Italy, of civil origin:

- 1541 - England: the Archbishop of Canterbury, Thomas Cranmer promulgates the restriction of ostentatious food consumption in the clergy (including turkeycockes) (cf. Eiche, Blay): "First (...) It was also probided, that of the greates fyshes or fowles, there should be but one in a dishe, as Crane, Swan, Turkeycocke, Hadocke, Pyke, Tench: and of lesse sortes but two, viz. Capons two, Pheasantes two, Conies two, Wodcockes two." ${ }^{2}$ - $1557^{53}$ - Italy: the Council of Venice passes a decree against luxury in parties, public or private (22 March 1557, De' Convitti): "it will be forbidden to serve partridges and turkeys (galli d'India) at parties, save in the following way: two of the following dishes may not be served together - roasts, turkeys or partridges - just as it will be illicit to serve during the same banquet turkeys and partridges, either together or separately." (Our tr.) ${ }^{54}$ (Zanon 1763: 32)

Sumptuary laws ruling the purchase and consumption of luxury birds including turkeys have been promulgated in several cities, in Bologna in 1553, in Parma in 1559, in Modena in 1563, in Cesena in 1575 and again in 1584 (De Grossi Mazzorin \& Epifani 2015: 59-60). In Venice, sumptuary laws about banquets aimed to reduce spending and competition between the great families which could lead to excessive debts and sometimes bankruptcies, and which greatly impaired the very supply of the city (cf. Faugeron 2016).

\section{Farming and distribution}

In the middle of the $16^{\text {th }}$ century in France, the turkey is not present on markets and is not part of the list of "poultry and game birds" which members of the poulterers' corporations are allowed to sell. As is illustrated in its absence from the order of 20 October 1546 taxing the prices of poultry (Lespinasse 1886: 347-348), in Charles IX's ruling regarding poulterers in 1563 (Le Grand d'Aussy 1782: 289), and his ruling for the Kingdom's general police of 4 February $1567^{55}$ (La Mare 1710: 1377). This means that, though turkey was already known and farmed, it was still only produced directly by or for noblemen for their own use, and unavailable to bourgeois ${ }^{56}$.

Gradually, its farming spread to the countryside. A few quotes confirm it:

- 1627 - Du Chesne Le pourtraict de la santé: "this meat is so common in France today, that the base court of the good houses, the barns and farmhouses of the villagers are full of it." 57

- 1705 - Lemery Traité des aliments : "The Turkey-Cock is a bird well known, and as much us'd for food, as Capon and Chickens (...)" (trad. Hay 1745) ${ }^{58}$

- 1751 - The Encyclopédie (Volume IV, p. 179): "Coq d'Inde: this animal is a very useful one in the farm; it multiplies a lot and often, \& its flesh is delicate when it is young."

- 1763 - (Northern Italy) Zanon Del'agricoltura dell'arti e del commercio: "Indian cocks and hens cover some of our countryside, they have become the food of farmers and small people; they lower the price of beef and veal and are the object of an active and predominant trade ${ }^{59}$." (Vol. I, pp.34-35, Our tr.).

Revue d'ethnoécologie, 19 | 2021 
In Italy, they have a reputation of being fragile animals when they are young, and aggressive when they are adults. Agostino Gallo publishes in 1565 his Dieci giornate della vera agricoltura, e piaceri della villa, in the form of a dialogue between Messer Giovanni Battista and Messer Vincenzo who is visiting him in Brescia. About the Indian cocks and hens, Messer Gio. Battista ends his description as follows:

"[...] And though their farming is quite expansive, however, being very delicate to eat, it is good to have some, and especially for each nobleman, to be honoured with friends, when cocks are really fat, like I have sometimes seen them, and once dead, they can weight up to thirty-five pounds each, knowing that the females barely weight half that, they brood their eggs permanently and each of them has sixteen to eighteen eggs. ${ }^{61}[. .]$.

To which his friend Vincenzo objects:

"I have never wanted to keep these birds, first because they die easily when they are little; and also because they are dirty, dishonest and horrible to look at because of their crests." ${ }^{62}$

\section{Gio. Battista answers:}

"When babies are born, you need to keep them in a warm place for a month, and not let them get out until they are covered with feathers or until it gets warm, they must not lack various cooked garden herbs, bread and ricotta [cheese]." (Our tr.) ${ }^{63}$

Florentine merchant Matteo Botti gives a good example of the difficulty to raise these birds, which he wanted to bring from Andalusia to his Tuscan farm: he lost his turkey, which had arrived sick, and then the four turkey chicks killed one another in a quarrel, 
leaving him nothing but the turkey hen (letter of October 1547). Following this failure, he stops trying to raise them, and ends up cancelling his order of three chicks, which are so expensive! (Orlandi 2011: 80).

The same year of Gallo's book, 1565, the first French text about turkey is not much more engaging. Here is the description of the Poulles d'Indes in Charles Estienne's Maison rustique, as translated in 1616 by Richard Surflet (Maison rustique, or The country farme):

"Of Indian Hennes. WHosoeuer he was that brought vs these birds from the Island of India, lately discouered by the Spaniards and Portugalls, whether wee call them Cockes or Peacockes of India; hath more fitted and prouided for the tooth than for any profit: For they may rightly be tearmed Cofers to cast Oates into, a deuouring gulfe of meat, and wherein there is no other pleasure to be taken, but onely in their crie and furiousnesse, when they are come to be great ones; or continually chirping whiles they be little: besides that, both the one and the other are ill-fauoured and ougly to behold, for the deformitie of their heads; for the male hath no combe, as our Cockes, but in stead thereof a red fleshinesse, and vnder his chinne a great wide and long throat, which swelleth and changeth into manie colours when he beginneth to be angrie. It is very true, that his flesh is fine and delicate, but without taste, and of hard digestion: And this is the cause why men vse to powder them, larde them much, and season them with Spices. There is much more pleasure and goodnesse in the flesh of a Peacocke." ${ }^{64}$

In 1569 again, the same argument leads Prudent le Choyselat in his Discours oeconomique (English translation of $1580 \mathrm{~A}$ discourse of Housebandrie) destined to take care of a household to "make the most" of a little amount of money, to choose raising common chickens, and definitely not Indian hens (poules d'Inde):

"And to make no longer discourse I advise yourself to bestowe your somme of money in buying of Hennes: not Meleagrides, the whiche Bellonius in his Peregrination affirmeth, to be our Hennes of the Indies (being the true Graniers of Otes) but common Hennes of our countrie: and housebande or employe them in suche sort, as I will drewe (?) hereafter. And be not impacient to attende the conclusion." $(1580)^{65}$

Noisy, gourmand and with tasteless flesh... Olivier de Serres in the Cinquième Lieu (fifth part) of his Théatre d'agriculture et mesnage des champs (1600) dedicated to "managing poultry, dovecots, warrens, parks, ponds, apiaries and silkworms" paints a different picture, and sort of answers Estienne. The chapter dedicated to "poulaille d'Inde" starts as follows:

"The convenience that one draws from the hen of India, because of the abundance of precious flesh, of which it honors the table of the lord in all seasons, \& the eggs that it gives at certain times of the year; overcome the difficulties of its breeding \& food, under which we wanted to govern this cattle, when it first came to our knowledge. Believing that because it is a foreigner, he could only live \& multiply here with extreme care \& expense. But the time master of the arts, taught us that these birds, be of fair maintenance without excessive cost, raise in almost any air, although the warm is the cleanest \& pleasant, as the closest to its natural, \& maintain with moderate care." ${ }^{66}$ (Our tr.)

He suggests another type of farming, not in the barnyards or even "left without care" around farms (where these birds are doing evils), in the wheat fields, vines, gardens and even prairies, which Estienne already condemned; he recommends the constitution of small herds of 6 to 7 dozens of animals, guarded by a boy who leads them

"walking through the countryside, finding lots of food, roots, vermin, herbs, grains of wild fruits of which \& free they graze very well." ${ }^{67}$ (Our tr.) 
the other hand, when kept in the barnyard, they naturally love food and are expansive in grain costs. And he concludes his chapter insisting on the size of the animal which makes a nice amount of flesh, without having to fatten it:

« As for fattening it, this is not necessary by special treatment: especially that by the ordinary food \& conduct, this poultry always stays to the point of being eaten." ${ }^{68}$ (Our tr.)

81 This type of farming will be adopted. One hundred years later, the practical recommendations match the ones in the Théatre d'agriculture. And Liger (1700) in the Oeconomie générale de la campagne (chapter VI, Des Poules-d'Inde):

"It is a good thing for the household, to have its courtyard filled with Chickens \& Hens of India. These birds make a lot of profit; \& no matter how hard it may be to raise them, we must not regret it; the pleasure of enjoying it in whatever way we please, easily compensates us for the care they cost us." ${ }^{69}$

He then lengthily explains how to raise this poultry, and make them reproduce ("the number of Indian Hens to give to one Cock"), care for the fragile chicks, and how "some little boy" can take the turkeys out to graze:

"In the morning, as soon as the Sun is up, we send out this little Turkey Man, to whom we strongly recommend not to abandon his flock, \& to lead him sometimes on one side, \& sometimes on the other, so that the diversity of pastures awakens the appetite of these animals, \& makes them grow as soon as possible. (...)When evening comes, this Turkey Man will lead his Turkey-hens in front of him, to put them in their Henhouse: but before enclosing them, he will carefully observe to throw some grain at them, to make them gain strength. The Mother of the Family will not fail also to make every evening the review of her Turkey-hens, \& to count them, so that the shepherd watches a lot on them, \& does not let any stray." ${ }^{\circ 0}$ (Our tr.)

83 We also find the following recommendations for turkey chicks farming in the Encyclopaedia (1751, Volume IV p. 1011): "there are no barnyard animal easier to raise. Cold is fatal to them." So they must not be taken out, or only briefly and in bright sunlight. They must be fed four times a day with preparations of breadcrumbs, chopped nettle leaves, bran, milled buckwheat, millet... "When they are strong, they are given to the dindonnier." This dindonnier, turkey-shepherd, is

"a boy-servant in charge of leading the turkey-cocks and hens to graze. Poultry are led in the fields only few times after sunrise. They are back in the farmyard around 10 o'clock, where they stay until noon, then back to pasture land till the evening." ${ }^{71}$ (our tr.).

The Trévoux Dictionnary (ed. 1771) supplements: "In several places in France, turkeys are taken out to graze in the countryside in flocks, like sheep." (sv. Dinde), and further: "Dindonnier. Shepherd, guide for turkey hens and cocks. (...) Dindonniers have large polepickers to lead their turkeys.".

"This bird is currently being naturalized in France; it has even become one of the most common ones. In late autumn, we see so many of them gazing in our lands that they seem to form some sorts of flocks.", Buchoz wrote in 1777 (Traité économique et physique des oiseaux de basse-cour, Liège, Desoer, p. 27).

Turkey breeding spreads along with its consumption and the custom of taking the flocks towards trading areas. Two testimonies on this custom, the first one by Vincenzo Tanara in Italy in 1644 in his Economia del Cittadino in villa, where he claims he has seen two hundred turkeys being taken by foot from the Kingdom of Naples to Rome, that being a journey of one hundred miles ${ }^{72}$, guided by boys (putarelli). In France, Le Grand 
d'Aussy relates that "every year, \& for more than a century, our Farmers from Querci and Périgord are taking entire flocks of turkeys all the way to the centre of Spain (...)" (Le Grand d'Aussy, 1782, p. 294).

In the beginning of the $19^{\text {th }}$ century, these transhumance movements towards markets become more important, as is illustrated in the prefects' survey in Indre (France) [Figure 5]:

"turkeys and geese are the types of poultry that are being farmed in the largest quantities (...) they are sent for grazing in flocks; they also have their shepherds, who are eight or nine year old boys in charge of their care: turkeys are also taken to the markets in flocks during the winter. The largest quantity is consumed in the country; however, some of it is sent to Orléans." Mémoire statistique du département de l'Indre, by Count d'Alphonse, prefect; Paris, Imprimerie Nationale, An XII [1803-1804], pp. 193-194

Figure 5: "Gardeurs de dindons dans les Landes de Gascogne " (turkey shepherds with their sticks), (postcard, postmark June 1914)

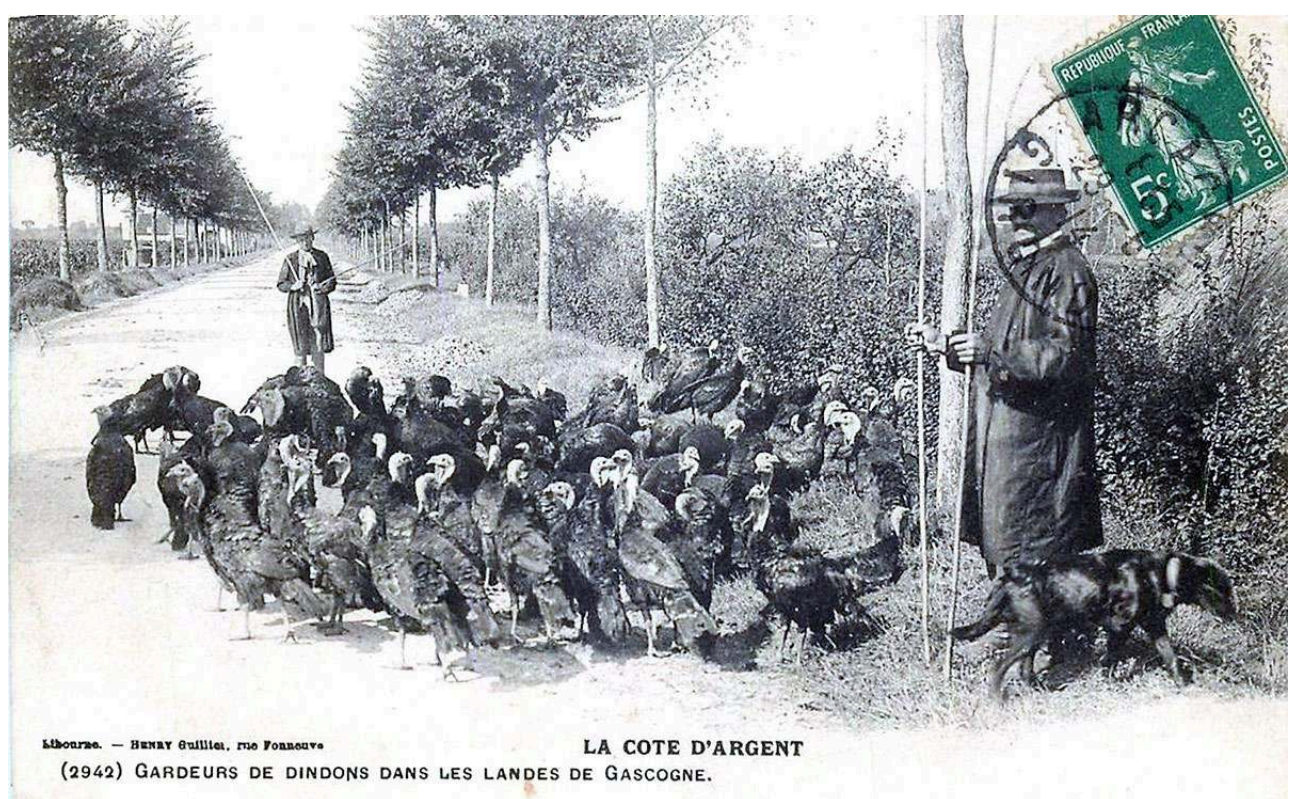

\section{The choice}

The turkey's initial reputation is that of meat that is difficult to digest, for instance: "Its pulp is double \& triple, \& similarly difficult to digest" "'3 (Savonarola \& B. Boldo 1576). Same prevention in France, expressed for example in Le thrésor de santé (1607), "Du Coq et de la poule d'Inde": "True is that their flesh is tender \& delicate, nonetheless it generates a big juice, digests awkwardly, \& abounds in viscosity, which is why it is good to sprinkle \& aromatize them." ${ }^{\prime 4}$. Hence the close focus on the proper age for consumption and in relation, the best season for slaughter and finally, the duration of preparation of the meat (hanging), and the right sauces and accompaniments (see following section).

88 Twenty years later however, the picture changed, and the animal was quite positively considered, as reflected by Joseph Du Chesne, counsellor and ordinary doctor of king Henri IV in his Pourtraict de la santé (1627) about the Indian cock: 
"It is a sweet, excellent, good and healthy meat, of easy digestion, a very good food, generating amount of good blood \& seed: it is a meat of the best, healthiest \& delicious to be found." 75 officier-tranchant (meat carver) of the German Embassy in Padua in 1639 [Figure 6]:

"The real season for Indian cocks and hens (Gallo e gallina d'India) is the coldest time of the year, and it being very tough meat, it is best to let them lie dead for a few days waiting for them to become more tender. The young ones should not be mentioned because they are not ordinarily slaughtered in our country, however, if someone wanted to eat them, they should know that the males must be at least four months old and the females (pollanche) five or six months old. ${ }^{80}$ " (Li tre trattati di Messer Mattia Giegher 1639: 5, Our tr.)

Figure 6: Turkey carving, Li tre trattati di Messer Mattia Giegher, 1639

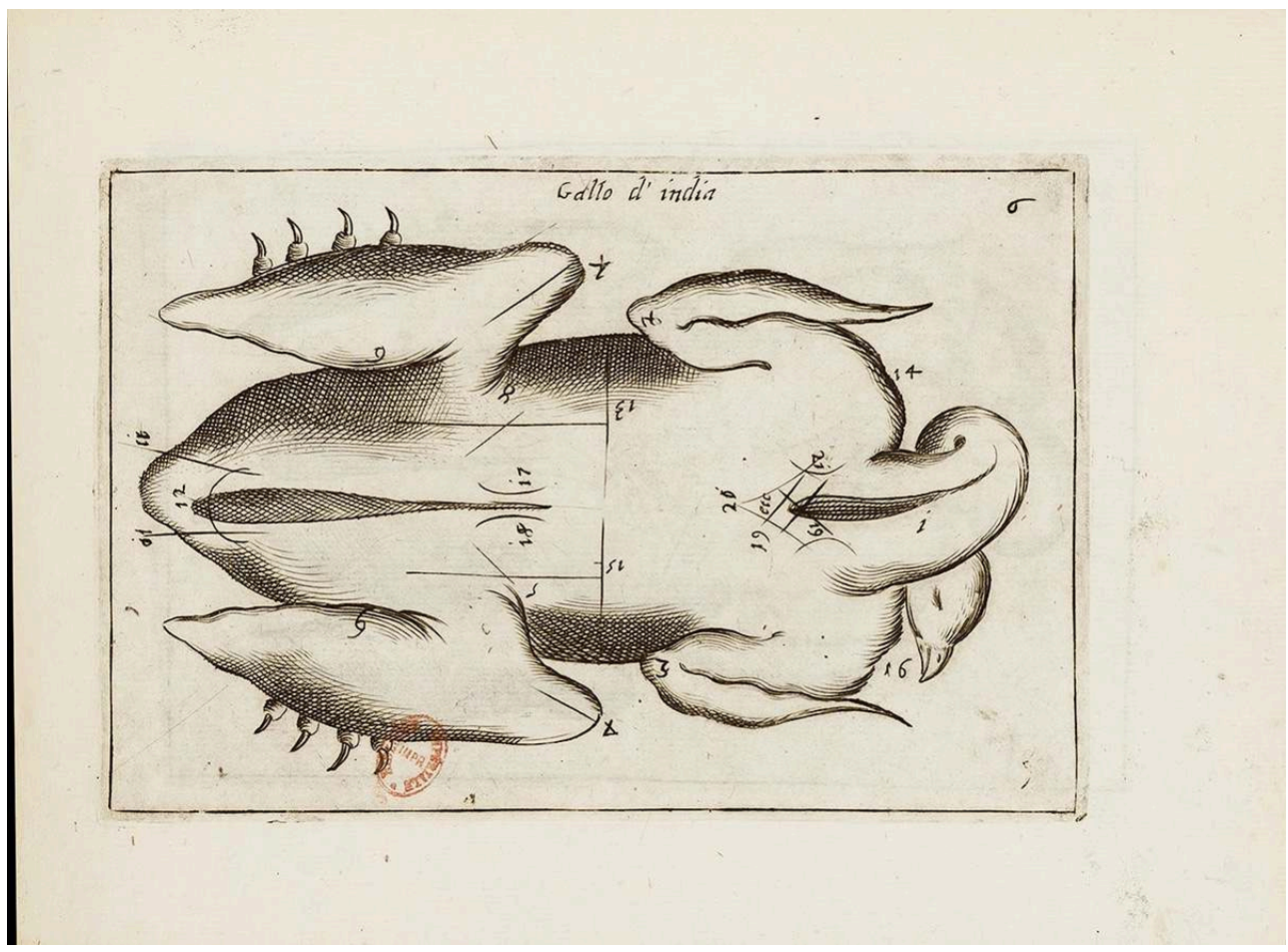

On the French side, according to Pierre de Lune, turkeys and turkey chicks can be served "at fine tables" throughout the entire year (on all four seasons). More specifically, the turkey cocks of the year are selected between Easter and Saint John's day (24 June), and the Indian chickens from Saint John's day to Saint Remi day ( $1^{\text {st }}$ October) when "these meats are at their best", and from Saint Remi day to Easter, the Indian chickens and cocks (La Varenne, Pierre de Lune). The French cooks give no 
recommendations about the hanging duration for turkeys after slaughter. But they do unanimously prefer young turkey chicks, and then turkey hens (females), and not that much the males (turkey cocks), considered tough and reserved for stew dishes. Let us look at Lémery's Traité des aliments (1705), translated by D. Hays in 1745:

"Of the Turkey-Cock. You are to chuse that which is young, tender, fat, and wellfed. (...) On the other hand, when it is grown a little oldish, the Flesh becomes hard, like Leather; and not easily digested." (p. 230) ${ }^{81}$ A Treatise of All Sorts of Foods: Both Animal and Vegetable, Louis Lemery, trad. D. Hays 1745, Londres

Marin specifies in Les dons de Comus (1739): "The old Turkey goes into dough \& in daube. The young Turkey, or the Turkey poult, provides more to the kitchen, or diversifies more." ${ }^{82}$ (Our tr.)

It is still the opinion of Le Grand d'Aussy in the end of the $18^{\text {th }}$ century:

"We, today, find its flesh, hard and dry. We only eat roasted turkey poults. For the turkey cock, it is served only in stew or pâté; unless it is stuffed with truffles, like those coming from the Perigord." ${ }^{33}$ (Histoire de la vie privée des Français, 1782: 293, Our tr.)

\section{How did the turkey get into our kitchens?}

Looking at printed cookbooks, country by country and in chronological order, I will try to grasp the place that turkey took over throughout the years. For some countries, I tried to see all the books; in others, I made a selection, in order to have examples for each era. I have not necessarily compared the successive editions, which for some successful books can spread out over more than a century (list of examined books is on Annex 1).

I must specify the historic place and function of this singular object that is the cookbook. We will note a disparity in the countries that we have studied here in terms of publishing dates, number of titles and even types of publications. We must also take into consideration that the presence of a certain type of food in a cookbook is not an archival proof of its introduction. Recipes are traces, not proofs, and the overview they offer is but a reflection, an image, of the conception we have of a certain type of food in a certain type of diet. Furthermore, cookbooks are meant for specific readers, and hence a list of recipes may not be considered the proof of an entire society's diet.

Up until the $15^{\text {th }}$ century, cookbooks were passed down through manuscripts, which were copied many times over (Laurioux 1988). Then the history of cookbooks follows the history of printing, but they are just one specific expression, while there are many other notebooks and manuscripts addressed to private users maintaining customs, and often orally passed down.

Cookbooks in the Middle Ages were first manuscripts being copied and amplified in the process through true "textual makeshift jobs" (Laurioux 1988). Small collections of recipes put together by professional cooks, as sort of reminder notebooks, were gradually supplemented with essential specifications for common users (injunctions), with a few new recipes here and there (truffle stuffing), and then with the addition of new texts. Among the books that were printed in the $16^{\text {th }}$ century based on medieval manuscripts, we may name in France Le Viandier (first version printed in $1486^{84}$, then until 1555), in Spain the Libre del coch (of the $15^{\text {th }}$ century, printed until 1529) and in England The book of cookerye (also in the $15^{\text {th }}$ century, and printed again around 1575). 
This set of processes acknowledged in the composition of the manuscripts is easily found in the successive printed versions of the books of the $17^{\text {th }}$ and $18^{\text {th }}$ centuries, with many examples: in Italy L'arte di ben cucinare by Stefani, published from 1662 to 1685, in Spain Arte de cocina by Altamira, published from 1758 to 1850, in France Le cuisinier roïal et bourgeois by Massialot and then La Chapelle from 1705 to 1742, in England The art of the cookery by Glasse, from 1747 to 1846 .

At first, printed cookbooks are essentially collections of recipes written by cooks to be passed down in good households ${ }^{85}$. Some also indicate how to look after a house, addressing the cook, the butler and even the écuyer tranchant (meat carver) (hence $L a$ singular dottrina by Romoli 1560, Li tre trattati 1639, or L'escole parfaicte 1662). Some books include standard menus associated to different seasons. Throughout the $17^{\text {th }}$ century, it seems that the users to which the books were addressed changed and that they were essentially addressed, no longer to cooks or princes but to bourgeois; we move from noblemen's cooking to bourgeois' cooking. For example, in France, we go from the Nouveau et parfait maistre d'Hostel royal by Pierre de Lune (1662) to Cuisinier roïal et bourgeois by François Massialot in 1705.

\section{Spanish books}

The first printed book, that of Ruberto de Nola, is known in three different versions; a first edition in Catalan (Art de coch, 1520), and then two editions in Spanish with different titles (Libro de cozina, 1525; Libro de guisados, 152986). Mestre Ruberto was (Spanish) King Ferdinand I's cook in Naples ${ }^{87}$, and that is why his book is considered to have been written in the end of the $15^{\text {th }}$ century. With terms identical in both Spanish editions, it includes 4 recipes $^{88}$ mentioning pavo (for sauces and stuffing), besides others with other birds (aves, for the cutting), chickens and capons (gallinas, capones). Given the dates of these publications, it is certain that it refers to peafowls.

$16^{\text {th }}$ century books do not mention pavo at all: Lobera de Avil, Vergel de sanidad (1542), Núñez de Coria Aviso de sanidad que trata de todos los generos de alimentos... (1572). Significantly, the $2^{\text {nd }}$ edition of Franciso Núñez de Coria's book, Regimiento $y$ aviso de sanidad (1585) just includes a descriptive paragraph ${ }^{89}$ at the end of chapter 16 about chickens, their chicks and capons (...), without changing the initial text, nor adding any recipe:

"There is also sorts of chickens from India we call peafowls in Spain because they have almost the same size and their feathers also have multiple colours." 90

3 Most of the Spanish books of the $17^{\text {th }}$ and $18^{\text {th }}$ centuries pay little attention to turkeys (except for one, which I will come back to): Domingo Hernandez de Maceras Libro del Arte de Cozina (1607, 2 mentions ${ }^{91}$ ), Francisco Martinez Motiño Arte de cozina pasteleria vizcocheria $\left(1611,1637,4\right.$ mentions $\left.{ }^{92}\right)$, Juan Altamiras, successive editions of Arte de cocina, (1758, 1791 and even 1850, with similar recipes, 2 mentions $\left.{ }^{93}\right)$. Throughout all these books, we note little interest for turkeys, compared to the number of recipes for hens, chickens and capons.

The exception is Diego Granado's book Libro del arte de cozina (1614, 6 mentions $\left.{ }^{94}\right)$. Some recipes explicitly concern "gallo y gallina de las Indias" and also polla de Indias which he seems to distinguish from pauos, as well as pheasants, chickens and capons ${ }^{95}$. I shall add that Granado's is the only book I have read that explicitly gives a recipe for guinea pigs: 
«pastel de conejo de las Indias» (p. $\left.89 \mathrm{R}^{\circ}\right)$. According to Allard (1988) and then Redondo Buey (2014), Granado's book is entirely based on Ruberto de Nola's (1529) as well as on Italian books by Bartolomeo Scappi $(1570,1610)$. It does seem like the turkey recipes are quite alike (Plouvier 1995).

The trend does not change throughout the $19^{\text {th }}$ century and the place of turkeys remains the same. I have read four publications (besides the republications of Altamiras): La nueva cocinera curiosa y económica y su marido de D. A. P. Z. G. (1822, 4 mentions $\left.{ }^{96}\right)$, Novísimo arte de cocina o aviso a la cocineras (1845, only one recipe $\left.{ }^{97}\right)$, Manual de la cocinera española y americana de M. Brecarelli $\left(1898,5\right.$ recipes $\left.^{98}\right)$. Three of these give recipes with giblets, wing tips, feet, liver, neck, gizzard. I left aside the Manual del cocinero, cocinera $y$ repostero $\left(1828,9\right.$ recipes $\left.{ }^{99}\right)$, which is the translation of the French Manuel Roret of 1826, Manuel du cuisinier ${ }^{100}$. The author, translator and adapter D. Mariano de Rementería y Pica, specifies that young turkeys are used in guisados (stews) and the old ones in adobo (marinade), and that turkey hens are better because they taste more delicate. But the original French book included 19 recipes ( 7 of which were on wing tips preparations)! The translator only chose some of them and significantly reduced it, probably to match his readers' tastes.

Allard (1988) draws our attention on the fact that these rare Spanish culinary treatises of the $16^{\text {th }}$ and $17^{\text {th }}$ centuries were written by court cooks. Two of them were considered pioneering in their own time and afterwards, and have achieved editorial successes, with multiple reprintings for over a century: Martinez Motiño, republished 25 times from 1611 to 1823, and Juan Altamiras, republished for a century from 1745 to 1850 . However, their pioneering aspect is not noticeable regarding turkeys.

On the contrary, the book of Granado, which brings more original recipes, was not very successful, with only 3 editions (1599, 1606 and 1614). Because it is a type of compilation (of Spanish-Catalan $15^{\text {th }}$ century on the one hand and Italian $16^{\text {th }}$ century on the other), Allard suggests that this low interest could be due to the "Italianness of most of the recipes and the ancientness of the others?".

In conclusion, turkeys do appear in $17^{\text {th }}$ century Spanish cookbooks, without raising much interest from the cooks who create very few specific recipes, even in the $19^{\text {th }}$ century; it is often one small choice among other types of poultry.

\section{Italian books}

109 The most important Italian book of the early $16^{\text {th }}$ century, Banchetti compositioni $d i$ vivande et apparecchio generale de Christoforo di Messisbugo ${ }^{101}$ (1549), gives many recipes for capons, chickens, poulardes, pheasants, pigeons, and even peacocks (pavo, pavoni), but not turkeys.

110 In the same way, the Trattato della natura de cibi e del bere by Baldassare Pisanelli (1583) raises a specific problem because though he talks about the qualities and uses of the Gallo d'India, next to capons and peafowls, he specifies in the "natural history" section: they are birds that were brought from Numidia and not from India, and are called Meleagrides by the Greeks ${ }^{102}$... So they were guineafowls, and not turkeys.

111 Afterwards, in the second half of the $16^{\text {th }}$ century, all books give an important place to turkeys, but the information mostly comes from the banquets' menus, more than from the recipes themselves. It is the case with Romoli, Cervio, Lancellotti and even Scappi. 
Several of these books were republished, most of the time with no changes (or very few): it is the case with Domenico Romoli (La singolar dottrina 1560, 1587), Bartolomeo Scappi (il Cvoco secreto 1570, Dell'arte del cvcinare 1610 [Figure 7]), Ottavio Stefani (L'arte di ben cucinare $1662,1672,1685)$.

Figure 7: The roasting chief and the meat-carver serving a table in Venice at $17^{\text {th }} \mathrm{c}$. (cover of Dell'arte del cvcinare Scappi 1610)

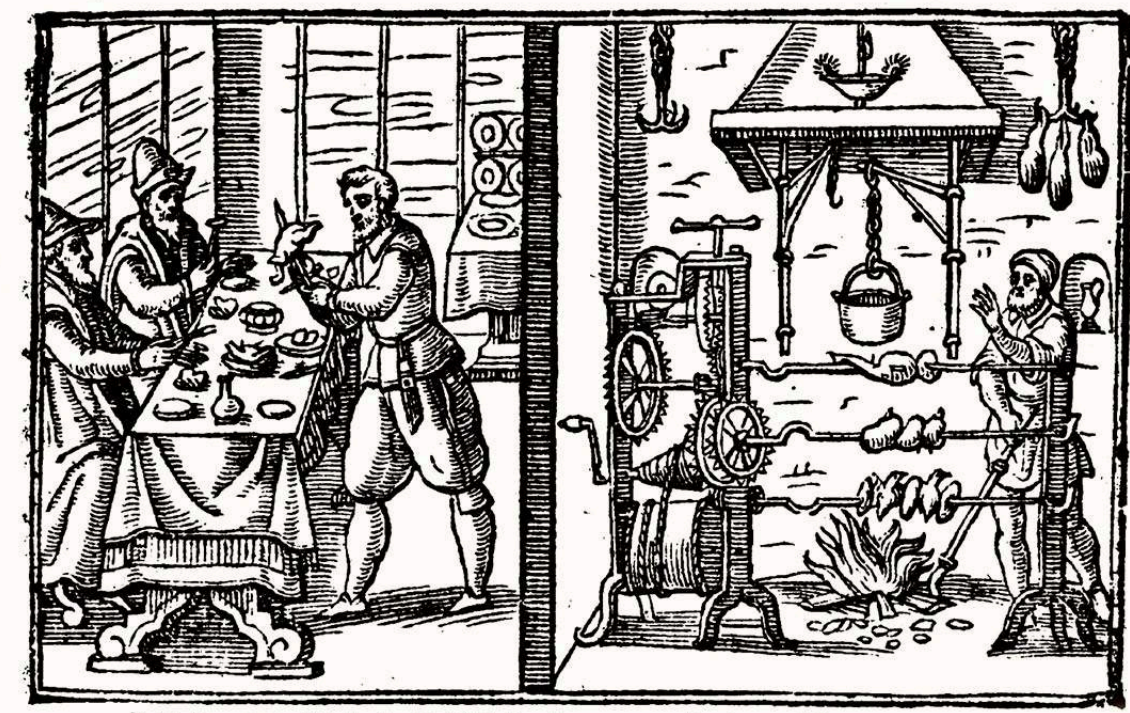

IN VENETIA, M. DC.X. PRESSO ALESSANDRO VECCHI.

112 In 1560, Romoli presented four turkey chicks or turkey hens dishes, and he added one in $1587^{103}$. The book of Vincenzo Cervio, Il trinciante ("meat carver", $1593^{104}$ ) is very famous because it contains a plate that was often reproduced which compares turkey cutting with peafowl cutting [Figure 8]. Describing several wedding banquets (such as the Prince of Mantua's in May 1581, and the duke of Paliano's in November 1589), he names eight stuffed turkey dishes (with ortolans, truffles), with various sauces (chards, green raviolis, asparaguses.... $)^{105}$. 
Figure 8: The roasting chief and the meat-carver serving a table in Venice at $17^{\text {th }} \mathrm{c}$. (cover of Dell'arte del cvcinare Scappi 1610)

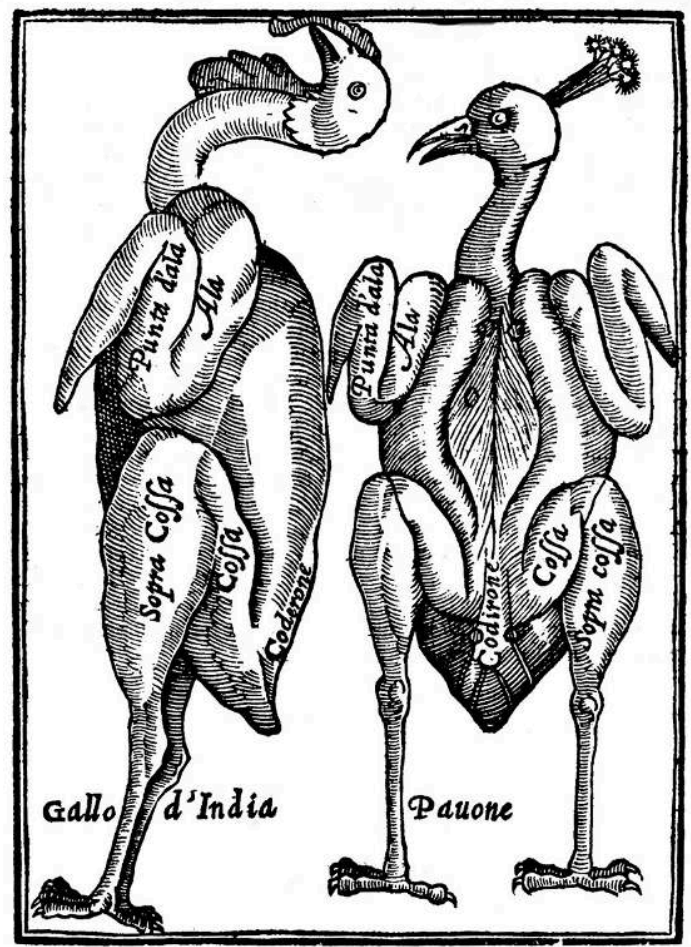

113 Two similar books by Bartolomeo Scappi ${ }^{106}$ stand out from among the others because they are so extended. Scappi, "the pope's secret cook", is considered the reformer of Italian cuisine, transforming the medieval heritage and inventing hundreds of recipes, which lastingly influenced not only Italian cooks, but cooks throughout all of Europe with translations and adaptations (and even plagiaries) in other languages (including Diego Granado in Spanish, as we have seen). Scappi dedicates paragraphs to the animals of the New World, the turkey (Gallo d'India), but also the Muscovy duck (Anatra d'India) and the guinea pig (Coniglio d'India) ${ }^{107}$. He mentions 31 dishes with turkeys, 10 recipes and 21 dishes listed in the menus. The recipes are mostly global directions to roast on a spit or boil all types of poultry, to use the giblets (livers, gizzards), and to make pâtés or consommés. The dishes are based on these roasts or broths [Figure 9], diversely stuffed (with plums, small birds or blackbirds, truffles, chards, ogliapotrida...) and prepared with a great variety of sauces (accompaniments: baste with bigarade juice, with quinces, small lemons; sprinkle with bits of lemon, anise, pitted olives, capers of various sizes, cheese, borage and parsley flowers, and almost always end by sprinkling sugar...). Scappi uses turkey cocks (gallo), turkey hens (galline), turkey chicks (pollanche) and small ones (pollanchette) ${ }^{108}$. 
Figure 9: A recipe for roast in Scappi, Cuoco secreto (1570)

\section{Per arroftire il Gallo, of la Gallina dindia, liquali in alcuni locbi d'Italia fi dimundano paroni d' India, cap. $\boldsymbol{C} \times \mathbf{L}$.}

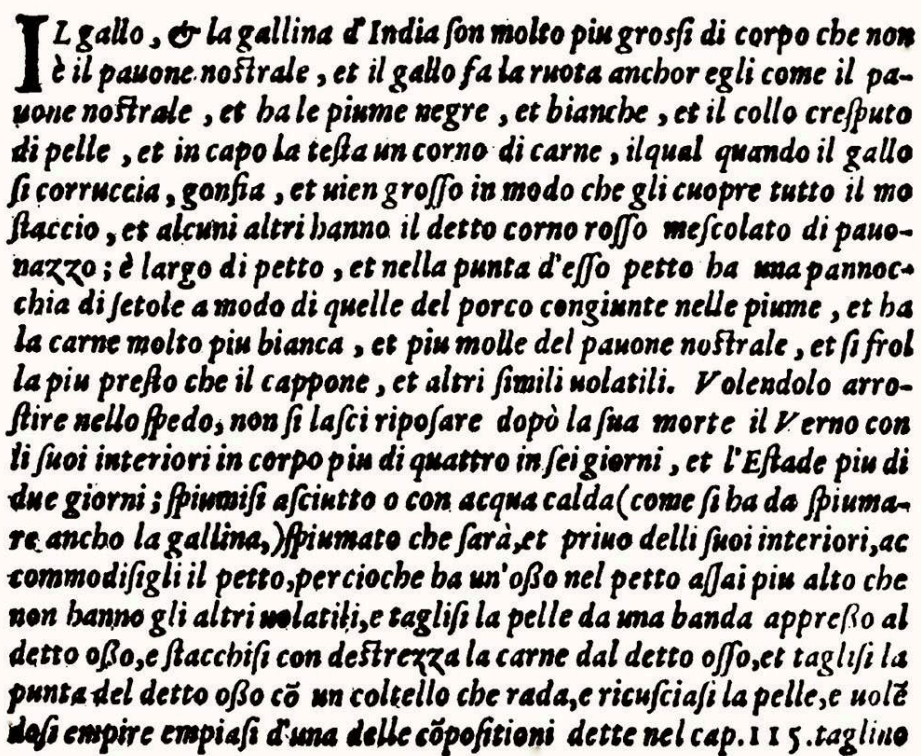

114 The book of Vittorio Lancellotti Lo scalco practico ("the practical steward", $1627^{109}$ ) is a collection of menus from banquets which took place between 1602 and 1627. The turkey cocks and turkey chicks are present in almost every service, in about twenty forms, sometimes used on several occasions: the poultry is roasted and larded (with lard, candied lemons, candied quinces), stuffed (with marrow, sausages "boiled in muscatel [wine]"), in pâtés (pasticci), richly shaped and decorated (with pastry leaves or marzapane [marzipan], golden and silver leaves...), in the shape of eagles, two-headed eagles, in oglio podrita with quails, accompanied by Spanish bread, roasted bread, pasta, etc $^{110}$. They are often served cold, usually in the first service. Two examples of these extraordinary recipes, showing luxury dishes for important figures:

Pollanchotte d'India arrosto assagianate, poi levate dalla carta, servite con fette di pane sotto, che era stato a mollo nel latte, indorate, e fritte, con salsa bastarda sopra, con fettoline di pane di Spagna intorno, in forma di lardoni, con copertoro sopra a gelosia, di zuccaro cannellato, tocco d'oro. (May 8 1603, Wedding of Duke Allexandre de Modene) [Large turkeys seasoned and roasted, then remove from paper wrapping (NB: to prevent dryness while cooking), served on slices of bread softened in milk, browned and fried, topped with bastarde sauce, with small slices of bread of Spain around, in the shape of lardons, covered with a lattice of sugar with canella, and a touch of gold]

Pollanchotte d'India arrosto, servite con un rosone sotta di pasta di sfoglio, e quattro vuoti, che in ogni vuoto era una pollancha, in mezo al quale era un vaso fatto di pasta di zuccaro, tocco d'oro, con una coroncina di zuccaro intorno al piatto tocca d'oro. (April 1622, meal offered by Cardinal Aldobrandino to illustrissime Ludovisi e Pio, for his unannounced visit) [Large roasted turkeys, served with a large rose of puff pastry, and four openings, in every there was a small turkey, and in the middle there was a vase made of sugar paste, with a touch of gold, and a crown of sugar around the plate, with a touch of gold]. 
115 Stefani (L'arte di ben cucinare, 1662), simply lists the 8 ways to cook a turkey (on a spit larded -, à la Swiss with wine and cinnamon, in a cooking pot with vinegar and butter, in the oven, on a grill - for the thighs ${ }^{111}$-, stewed with rosé vinegar or Tuscany oil -, in cold "eagle-shaped" pâtés). He then gives an example of a dish in the $3^{\text {rd }}$ service of a banquet for a Pre-Lenten day between August and October ${ }^{112}$, with a "table equipped in the richest possible way".

Finally, I will end this mention of the Italian meals with Il cuoco galante by Vincenzo Corrado ${ }^{113}$ (1773), who lists 15 ways ${ }^{114}$ to cook the birds he now calls "Tacchini, o Galli d'India". He specifies that they can also be cooked like capons, including their livers.

Turkey hens and cocks play an important part in the Italian noblemen's banquets and meals starting the second half of the $16^{\text {th }}$ century and all throughout the $17^{\text {th }}$ century, with especially creative and diversified accompaniments ${ }^{115}$.

\section{French books}

118 When Le cuisinier françois was published in 1651 by François Pierre known as La Varenne (1618-1678), it had been a century since any cookbook had been printed. And this one is not a reprint of medieval books, the most famous one being Le viandier de Taillevent, of the $15^{\text {th }}$ century, which was printed again in 1555. Meanwhile, a new cuisine has been formed, and Le Cuisinier françois is its first literary demonstration (Flandrin et al. 1983: 13). This book is the great success of the century, with some forty new editions for 50 years. It is the first one of an intense series: in 20 years, 8 different books, each of them numerously republished! Cookbooks are on-trend (cf. Flandrin et al. 1983: 100-105)

119 Le Cuisinier françois by La Varenne (1651) dedicates a dozen recipes to "poules, poulets and cocqs d'Inde, d'indonneaux" in the form of soups, daubes, stews, pâtés. He clearly prefers the use of young ones ("chickens"); he describes complex stuffing recipes, with squabs' giblets ("beatilles"), chestnuts, mushrooms and truffles, and a recipe of "poulet d'Inde à la framboise farcy", where you add, depending on the season, a handful of raspberries on the dish before you serve it! [Figure 10] 
Figure 10: Turkey recipe with raspberries, in La Varenne (Le cuisinier françois, 1651)

$$
\begin{aligned}
& \text { Fan çor so } \\
& \text { Maniere d'apprefter les viandes des } \\
& \text { Entrées, dont la Table eftcy-defjus. }
\end{aligned}
$$

I. Poulet d'Inde à la Framboife.

Apres qu'il eft habillé leuez en le bricher, \& tirez la chair que vous acherez auec graiffe \& peu de chair de veau, que vous meflerez enfemble auec ieaunes d'œufs \& pigeonneaux, \& le tout bien affaifonné, vous remplire $z$ voltre pouler d'Inde auec fel, poivre, cloubatu, \& ca* pres, puis le mettez à la broche \& le faites tourner bien doucement; eftant prefque cuit, tirez le \& le metrez dans vne terrine auec bon bouillon, champignons \& vnbouquet: pourlier la fance prenez vn peu de lard coupé, le faites paffer par la poëfle, lequel eftant fondu yous tirerez, \& y mettrez vn peu de farine que vous laifferez bien rouffir, \& delayerez auec peu de boullion \& du vinaigte; la mettrez en fuite dans voltre terrine auec ius de citron, \& feruez : fi c'eft au temps des framboifes, vous y en mertrez vne poignée par deffus.

Soon after, Pierre de Lune publishes Le cuisinier (1656) with 15 recipes for turkey cocks, turkey chicks, Indian hens, Indian chickens, Indian cocks. He makes them in soups (with white cabbage, morels, cucumber), in cold or hot pâtés (including a "pasté" à la Portuguese with cinnamon, lemon peel, Eastern dates, pistachios, plums, Corinth raisins, and lard...), grilled, in pot pourry, roasted - specifying that "turkey hens and chicks must be basted while roasting with a trickle of vinegar, spring onion, a little bit of salt and white pepper.". The flesh of the breasts is used to make white pudding, and various types of stuffing (including the one for the lamb's head dish). In a later book, (1662), Pierre de Lune adds a "Traitte de cuisine à l'espagnole" which contains several turkey cocks recipes $^{116}$ with crushed almonds, cinnamon, or white wine, chestnuts, plums, lemon peels, or even lard, macaroons, Corinth raisins, Eastern dates, pine nuts... [Figure 11] 


\section{Poulets-dinde defojiz.}

\section{Faites farce auec la mefine chair \&} lard, marons, formage, \& jaunes d'œufs; eftant farcie, paffez la à la poele, \& la faites cuire dans vne terrine auec bouillon, \& quand elle fera cuite, \& le boüil lon confommé, mettez capres, formage rapé, fafran, \&ziaunes d'oufs.

L'escole parfaicte des officiers de bouche (1662) just like L'art de bien traiter by L.S.R. (1693) confirm the use of turkeys of all ages, with a preference for the young ones of the year, in all preparations, roasts, daubes, stuffing, pastez, insisting on the quality of the breast: "breast is the most delicate part" (...) "make sure you always cut as much stomach as you can, because as I have said, it is the most delicate piece" as the "Officier de bouche" insists in his section about the "Dissection du Coq-d'Inde". [Figure 12]

Figure 12: «Dissection du Coq-d'Inde » in L'escole parfaite des officiers de bouche (1662)

Lie Grand Efcuyer.Tranthant. 39

Diffection du Coq-d'Inde.

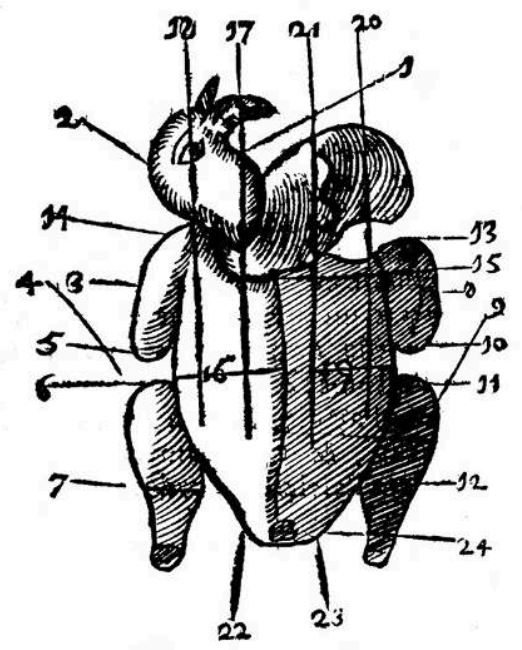


The cuisinier roïal et bourgeois by Massialot is richer in its second edition of 1705 which includes some twenty recipes dedicated to young ones (turkeys) or Indian chickens, some of them dedicated to big pigeons or capons, as well as a list of dishes in a choice of menus for each month of the year (soups, roasts, pâtés, pot-pourri, daubes ${ }^{117}$, salmi). I will only name a few mouth-watering or mysterious titles: small turkeys with white chicory, turkey chicks soup with morels stuffed with white cabbages, Indian chickens $\grave{a}$ la Swiss \& fried with cucumber, turkey with ham sauce, turkey filets with cucumbers... He presents two recipes that he really likes because, he says "these two are probably the most recent \& hence the ones that deserve to be mentioned first.": first course of turkeys stuffed with herbs (the space between the skin and the flesh is stuffed, and then the turkey is roasted on a spit), and another one with onion essence (to accompany roasted turkeys). Massialot's book will be taken over and completed by Vincent La Chapelle, in 1735 , and again in 1741 (Le nouveau cuisinier royal, in 3 volumes, presented in the form of a dictionary). These two editions also present an incredible number of recipes, of all types, including several ones for wing tips [Figure 13].

Figure 13: List « des entrées de dindons et dindonneaux » in the summary of the Cuisinier moderne by La Chapelle (1735)

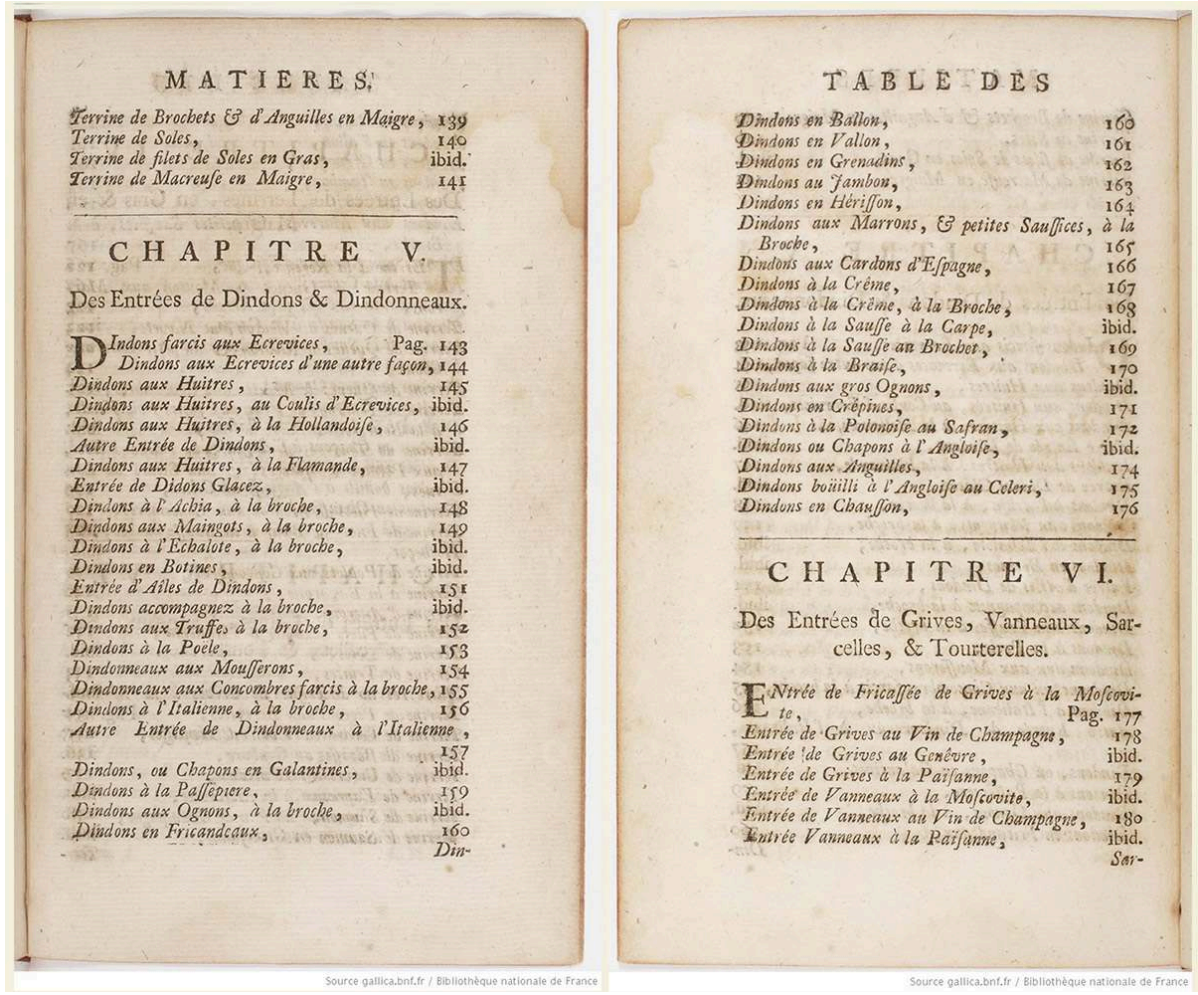

With 42 recipes, Menon's Nouveau traité de cuisine (1739) dedicates an entire section to turkey hens and cocks, which he uses at all ages, the young ones whole on a spit, the old ones in daubes, in filets (in blanquette or with bechamel sauce), cutting them and separating the "giblets" (wing tips, feet, neck, liver, gizzard) and the thighs: "You remove the thighs to prepare them (...); you are left with the wings and stomach for your escalope. The carcass is placed in the pot to eat with coarse salt." The Indian poultry is turned into bread, galantine, balls, rolled, in brézolles ${ }^{118}$; the wing tips are the object of no less than 19 recipes (with onions and cheese, in fricandeau, en matelotte, with green mash, with Champagne wine, with crayfish, à la Spanish, with Parmesan...). The later editions 
(La cuisinière bourgeoise, 1746 and 1775) are less detailed but just as diversified regarding types of cooking. ${ }^{119}$

In 1739, Les dons de Comus ou les délices de la table by François Marin goes even further with 74 recipes. I quote:

"The old Turkey goes into dough \& in daube. The young Turkey, or the Turkey poult, provides more to the kitchen, or diversifies more. The body goes to the broach \& roast: for entry it is put to the shallot, in whole fillet with truffles, in galantines, oyster roll, \& with pickles. Wings \& estomach are eaten glazed in their juice. (...)" ${ }^{\prime 120}$ (p. 38, our tr.)

He separates the wings tips, the filets, the (stuffed) feet, the liver, the giblets, and makes cascaloppes, he makes pies, pâtés, terrines, galantines, ballotines, daubes, pots, soups, fricassees, and of course roasts. Les dons de Comus, is the high point of turkey cooking, which is made "in countless other ways (...) depending on the Officer's abilities and the Master's tastes." in his own words!

I will end with the evocation of the $19^{\text {th }}$ century cuisine, which still leaves an important place to turkeys, by quoting André Viard's Le cuisinier impérial (1806):

"There would be too much to say if we were to describe all the dishes you can make with this bird: the best ones are the young and fattest ones."

Figure 14: Poultry carving in Manuel Roret du cuisinier (1826)

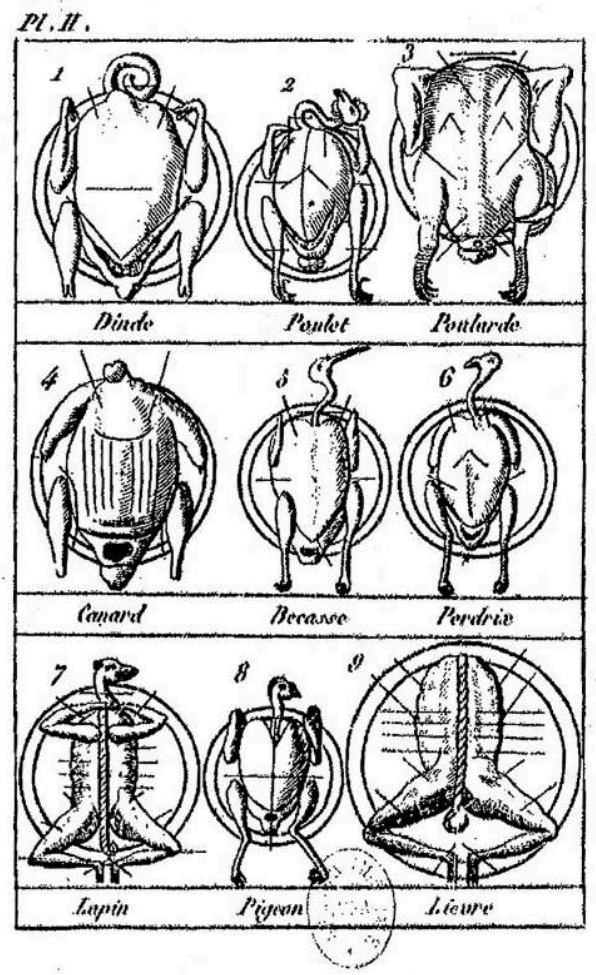

The turkey, at all ages, has an important place in French cuisine starting from the $17^{\text {th }}$ century and many recipes and preparations are dedicated to it all the way to the $19^{\text {th }}$ century, with a high point in the middle of $18^{\text {th }}$ century. 
Figure 15: « 1-Dindon cru sur broche. 2- Dindon rôti débroché » (1- raw turkey on the spit, 2- roasted turkey out of tbe spit) in Le livre de cuisine by Jules Gouffé (7th edition, 1888)

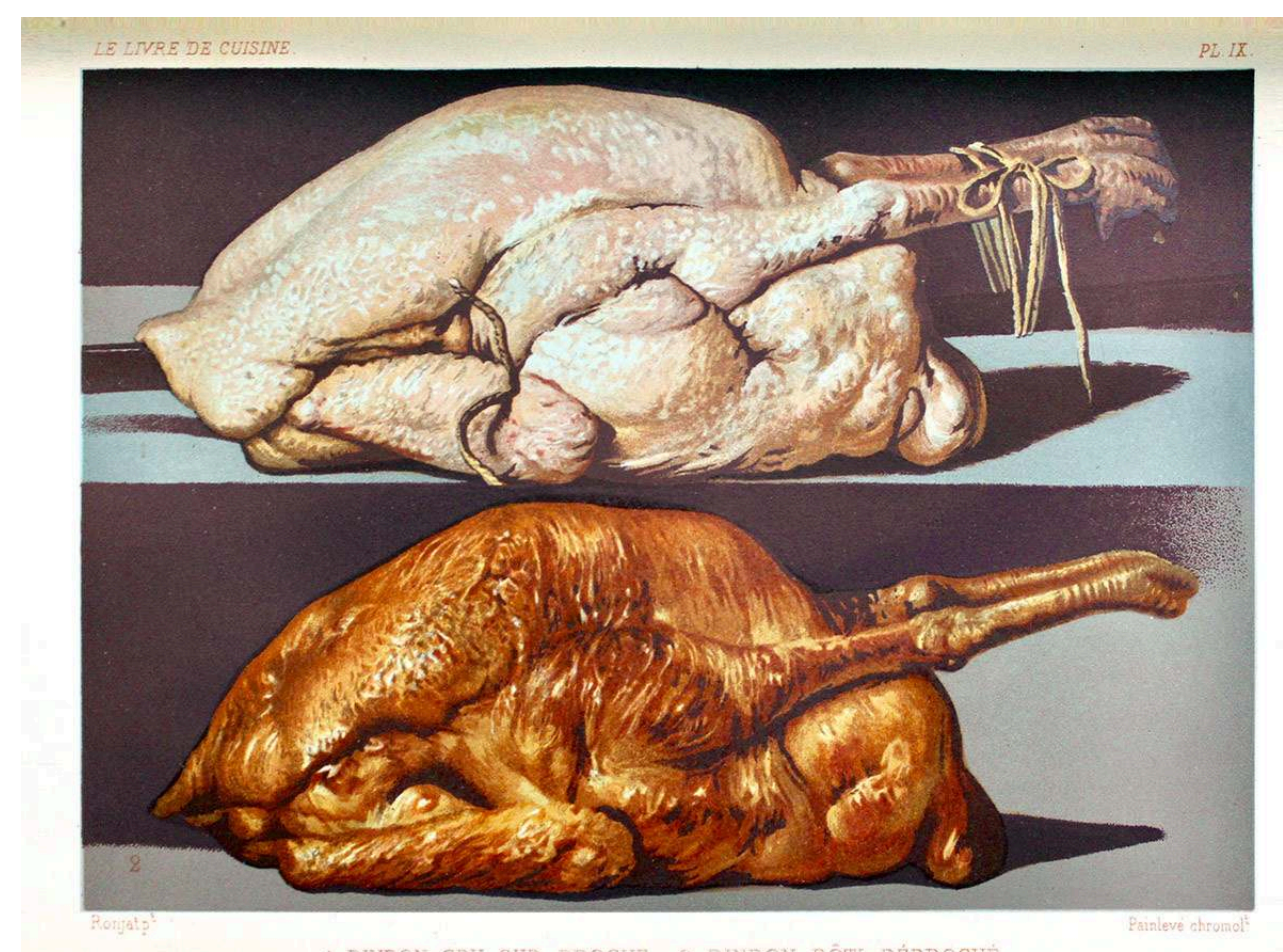

\section{English books}

A proper new book of cookerye, the most ancient book that was read for this study, printed around 1575 , is actually a $15^{\text {th }}$ century book. Obviously, it does not mention Turkey, but it presents recipes with large birds, peafowls and swans (Frere 1913).

A Book of Cookrye in 1584 by A. W., from London, gives two recipes for Turky Fowles: a sauce with onions and pepper to accompany, and a way to bake, boned and with smashed pepper, salt, and "a good helping of butter inside" and which takes five hours to cook...

Afterwards, and until the middle of the $17^{\text {th }}$ century, almost all books present some recipes of the entire Land-Fowls (geese, swans, pheasants, capons...), which includes Turkies, and sometimes namely just turkey cocks: The good husvvifes Ievvell by Thomas Dawson (1587; 1 recette), The good Huswifes Handmaide for the Kitchin (1594, 2 recipes), The English Hus-wife by Gervase Markham (1615, 4 recipes), New book of cookerie by John Murrell (1615, 1 recipe), until Hannah Wolley's The cooks guide (1664, 1 recipe). Some do not mention turkeys at all (The Compleat Cook, 1658).

131 The basic recipes involve roasting and oven cooking, usually boned. Other types of preparation appear, pâtés (pies) first, but also carbonade (charbonadoes ${ }^{121}$, "the invention thereof was first brought out of France as appears by the name", Markham in 1615). The only recipe in Wolley's The cooks guide 1664) is very singular, but it is then found in several other books, "To sowse a Turkey" 122 [Figure 16]: the bird is boned and boiled in water and wine spiced with mace, clove, salt and pepper; in the end, you place it in an earthen pot which is filled with the lightened broth, completed with white wine, vinegar and salt. 
Carefully hermetically sealed, it is left for 12 to 14 days in cool storage before being opened and eaten... We also find this recipe, To souce Turkeys, in Nott 1725 (left in storage for 3 to 4 weeks), in Robert Smith's Court Cookery: Or The Complete English Cook (1725 also, in storage for a month) and again in Elizabeth Raffald's Experienced housekeeper (1769).

Figure 16: "To sowse a Turkey" in The cooks guide by Hannah Wolley (1664: 51)

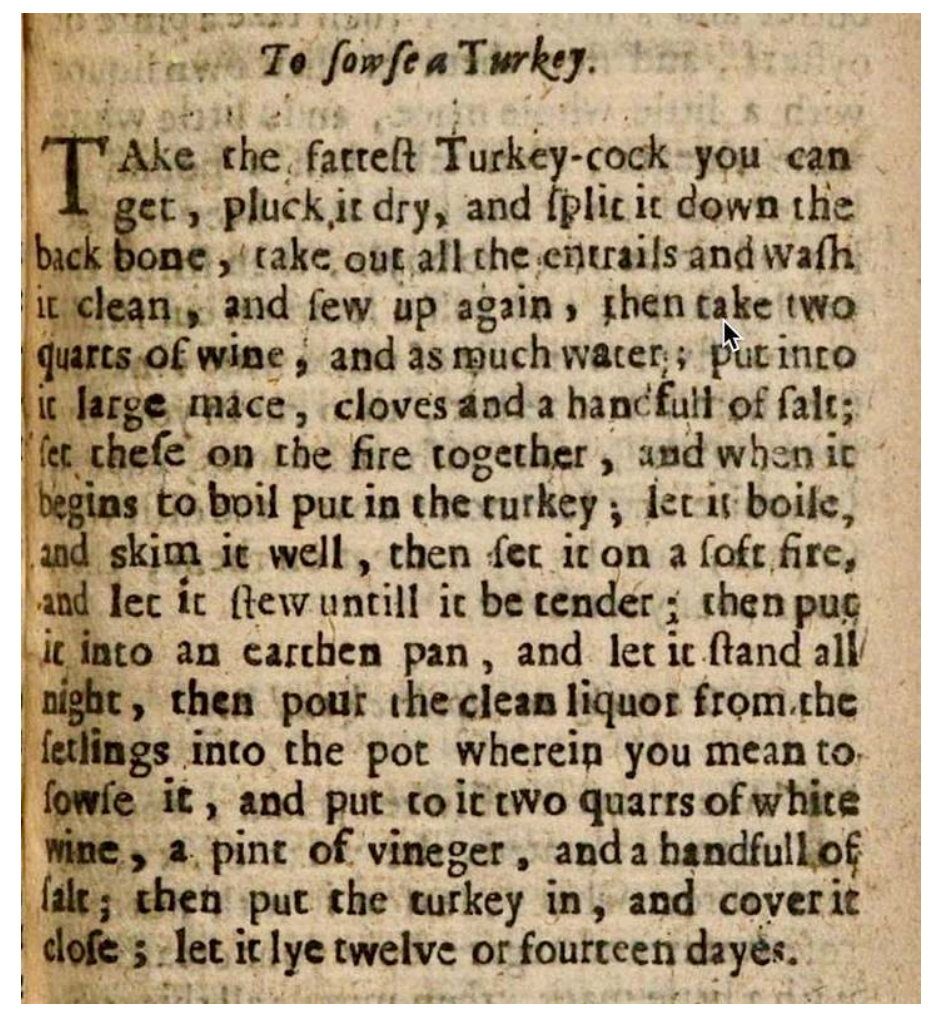

Books of the late $17^{\text {th }}$ and $18^{\text {th }}$ centuries focus more on turkeys, but not necessarily independently from the other types of poultry, however.

Except for The England new way of all sorts of cookery by Henry Howard (1708, only 3 recipes), The Compleat Housewife by Eliza Smith (1737, 4 mentions, including one sauce $\left.{ }^{123}\right)$ and The House Keeper's Pocket book by Sarah Harrison (1739, 2 recipes and 2 sauces ${ }^{124}$ ), the others present more diversified preparations, in addition to the traditional roasting, pies pâtés and suggest several different sauces to accompany the poultry. So Cookery dissected by William Rabisha $\left(1673,7\right.$ recipes $\left.{ }^{125}\right)$, the already quoted The Cooks and Confectioners Dictionary by John Nott, $\left(1725,8\right.$ recipes $\left.{ }^{126}\right)$, and Court Cookery by Smith $\left(1725,6\right.$ recipes ${ }^{127}$ ) [Figure 17], The art of cookery by a Lady [Hannah Glasse] (1747, 15 recipes $\left.^{128}\right), A$ new and easy method of cookery by Elizabeth Cleland $(1755,6$ recipes ${ }^{129}$ ), Experienced housekeeper by Elizabeth Raffald (1769, 7 recipes $\left.{ }^{130}\right)$ and finally The Art of Cookery Made Easy and Refined by John Mollard (1802, 10 recipes $\left.{ }^{131}\right)$. 


\title{
The Compleat Englith $\mathrm{COOK}$. 25
}

\author{
To boil a Turkey with Oyfters.
}

\begin{abstract}
T Ake half a Pint of Water, half an Anchovy, three fpoonfuls of Oyfter $\mathrm{Li}$ quor; thicken it well with Flower over the Fire; then ftew your Oyfters with the reft of the Liquor, and two Blades of Mace, and a little whole Pepper; then take out your Oyfters, and ftrain all the Liquor: When your Turkey is almoft ready, put all your Sauce together, with a piece of Butter, and a fpoonful or two of Gravy, a fpoonful of White-wine, a little Lemon-Juice, and thake it over the Fire, and pour it over the Turkey, and ferve it.
\end{abstract}

134 In the meantime, the translations of two very important French cookbooks were published: in 1653 The French Cook by La Varenne (Le cuisinier français, 1651), and in 1702 The court and Country Cook by Massialot (le Cuisinier roïl et bourgeois, 1691), with many turkey recipes as we have seen. These books have undoubtedly influenced the English books of the time.

G. Lehmann (1999) distinguishes several periods in the publication of cookbooks, which were all very successful:

- Books based on manuscripts collections of aristocratic families' recipes, written by men and addressed to the rich gentry, often addressed to House-wives (between 1580 and 1650 , late $16^{\text {th }}$ century mid $17^{\text {th }}$ century);

- Starting the end of the $17^{\text {th }}$ and mostly during the $18^{\text {th }}$ century, books addressed to the bourgeoisie (who have no desire to imitate the aristocratic fashion). Mostly written by women for women, these books based on their personal experiences and practices will all be very successful, with many republications throughout the century and after (starting the $2^{\text {nd }}$ half of the $18^{\text {th }}$ century).

136 English turkeys are usually prepared like the other poultry, being roasted, boiled, in pâtés, with a few specific sauces (fricasey, ragoo...), in salads (called sallet, salamongund ${ }^{132}$ ), and with a singular maturation mode, sousing, a several weeks-old marinade. However, there are very few recipes specifically meant for turkeys. They all require a lot of butter, as well as spices and herbs, white wine, vinegar, verjuice and lemon juice. 


\section{Portuguese books}

137 Portugal clearly stands out from among the other countries in terms of cookbooks, with its very small number of printed works, almost one for each century, and the absence of any book before 1680. The first cookbook printed in Portugal is Arte de cozinha by Domingos Rodrigues (1637-1719), whose first edition in 1680 will be followed by 11 others until 1844. It will be replaced in 1780 by the Cozinheiro moderno ou nova arte de cozinha, by Lucas Rigaud, which will be republished five times until 1826.

One of the key features of these two books is that they are widely open to other countries' cuisines, especially in the names of the recipes. Both authors were professional cooks who had worked abroad before working in Portugal, and Rigaud knew, and may even have been inspired by, Vincent La Chapelle's book, Le cuisinier moderne, published in 1735. (Braga 2006, Gomes 2016). That is why it was said that Rigaud pursued the path opened by Rodrigues to "bring European cuisine to Portuguese tables" (Gomes: 248). Turkey is very present in both books, with recipes specifically dedicated to it, and its potential participation in recipes with other types of meat, poultry (chickens, capons) or even veal or beef.

Rodrigues (Arte de cozinha, 1680) dedicates 7 recipes to perù (or perum in the first edition) $)^{133}$ - in meatballs, stuffed turnovers, roasted and boned or not, with various sauces, in sausage meat. He also describes 18 other recipes that can be made with turkey. For these, he uses the bird, or its thighs (gigote), in pies (pasteis) or in pâtés (empadas), in soups, in French style soups, in roast, in estouffade... with a multitude of accompaniment sauces. Finally, by giving typical menus for each month of the year, he tells us how he chooses: females (peruas) are served in the winter (January, February, November), and males (peruns) from summer until November ${ }^{134}$.

Lucas Rigaud dedicates 32 recipes to peru, entirely roasted or braised, boned, for the breasts (peito), the thighs (coxas) or the wings (alerões). The foreign influence appears in the names and the ingredients (à la Provençale, with tarragon sauce, à la Périgord, Italian style, à la Montmorency, with Parmesan cheese).

141 In the $19^{\text {th }}$ century, turkey is still very present. In the Cozinheiro completo (1849), only 3 recipes $^{135}$ are dedicated to peru, but 7 others can apply to it as to other meats (poultry or beef), and 4 others are named in menus suggestions ${ }^{136}$. The last book that I have read is the Cozinheiro imperial by R. C. M., published in Rio in $1840^{137}$. The turkey (R. C. M. specifies that the flesh of the female is more tender than that of the male) is very present, since no less than 50 recipes are meant for it, 30 specifically, and 20 for which turkey is an option among other types of poultry. We even recognize several recipes from anterior books (note that the Arte de cozinha by Rodrigues was published in Rio in 1838). Among the specificities, preparations with rice ([peru] com arroz, Portuguese style, Persian style), in pâtés empadas, several preparations for boned wings (azas). Unfortunately, I could not find and read João de Matta's book Arte de Cosinha (1876).

In the $17^{\text {th }}, 18^{\text {th }}$ and $19^{\text {th }}$ centuries in Portugal, and then in Brazil, turkey is very present in modern cuisine, same as the other types of poultry, and even in the context of European influences, with recipes inspired from France or Italy. 


\section{Conclusion}

From the first look on the new continent, these large birds that the natives ate seemed remarkable and delicious to conquerors. Introduced in Spain before 1511, turkeys are reserved for noblemen, people worthy of it, and who find it decorative enough to place them in their aviaries or gardens, like they do with peafowls. They start appearing in their banquets like the other large luxury birds that are peafowls, geese, swans and bustards. Through relations between the great families, the turkey settles in Italy, where it is spotted in 1520, and in France, where it was known before 1534. In England, it is also present before 1541 .

In the middle of the $16^{\text {th }}$ century, less than fifty years after it was discovered, this bird raises such enthusiasm in the upper classes that they start farming it, outside the royal aviaries, and through regulations, try to restrict its excessive consumption (in England, in Northern Italy).

After a rough start, because the turkey chicks seem too fragile and are subject to such high mortality rates, the farming is under control with small guards who take the birds out to graze. In less than a century, we go from a few birds in noble gardens to entire flocks of hundreds of turkeys, in farms, that supply cities' markets.

This phase matches the acclimatization period, the time to learn how to farm it, and the time for the cooks to learn how to use it and define the appropriate types of cooking and appropriate ages for consumption (the females and the young ones for the roast, the males for stews or pâtés).

The bird becomes essential in banquets and sumptuous meals; all great cooks of the noble Italian houses (in the $16^{\text {th }}$ century), then in France (in the $17^{\text {th }}$ century) and in Portugal (in the $18^{\text {th }}$ century) dedicate many recipes to them - but very little in Spain, strangely. In the middle of the $17^{\text {th }}$ century, the bourgeoisie appropriates turkeys, as is illustrated in the French and English cookbooks.

The menus presented in the books written by the great cooks show that turkeys settled right next to capons and chickens, replacing the geese that seem pretty marginal and peafowls which disappear completely from the aristocratic tables in the middle of the $17^{\text {th }}$ century. We know that in the $16^{\text {th }}$ and $17^{\text {th }}$ centuries, in various European countries, banquets were organized in a succession of a variable number of "services", each of which included many dishes placed simultaneously on the tables. The order was strictly codified with (at least) a first course, followed by roasts, pudding, and then an "issue de table" which ended the meal (see Flandrin 2002). Turkey preparations are present in all these services, in various forms, admittedly less frequently than chickenbased dishes, however [Figure 18]. Turkey was right for various preparations, and it was served in hot and cold pâtés, in daube for the puddings, and in roasts for the $2^{\text {nd }}$ service (see Flandrin 1992). By illustration, see the three-services meal for the supper of King Louis XV on 29 April 1751, which Flandrin reproduces (plate 1, front p. 160): turkey is present in the starter courses (dindonneau en tachette and dindon à la gelée) and in the Rôt (rosts de dindons). 
Figure 18: Menu and plan for a table of 15 places, in Le cuisinier moderne by Vincent La Chapelle (1735)

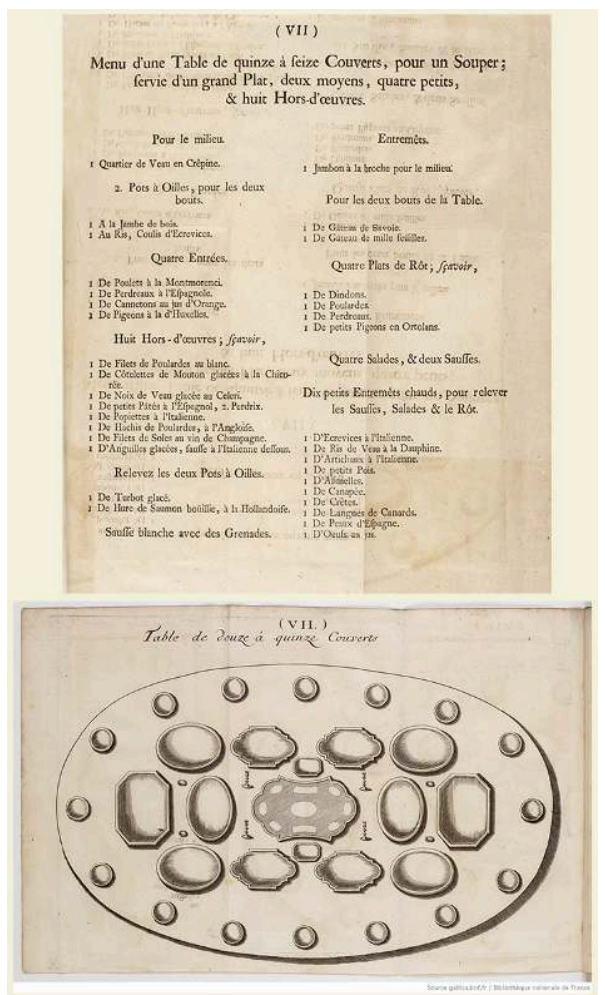

That is how this American bird took its place in the flock of European farm animals; it is firmly adopted within less than 150 years after its introduction. After the initial period when it was considered ugly and tasteless, the size and quality of the flesh, once the choice is controlled, make turkeys become essential, without meeting with any lasting resistance.

Bray (1993) had hypothesized the general principles regarding the adoption of products from the New World:

"1) Items that fill a vacant "cultural niche" are easily assimilated.(...) 2) Items that duplicate the role or function of an established product are likely to meet resistance.(...) 3) Items so exotic that they fall completely outside the frame of reference of the receiver-culture, or that conflict with entrenched beliefs and values, are likely to be rejected.(...)" (1993: 320-321)

Without deciding on the case of the turkey, we understand that according to him, it is part of the second category, that of a certain form of resistance.

For Flandrin, on the other hand (1992: 72), the turkey was accepted quickly "practically as soon as it was introduced", which he explains by the fact that "Europeans from the Middle Ages ate all sorts of birds (...) No problem with eating turkey, then, especially as the aristocratic tables were very fond of large and beautiful birds.", according to the principle he states: "When a new type of food is adopted by a people who did not know it existed before, it is usually because it is comparable to another type of food that is traditional for the people in question."

However, we may consider that turkey has been through an observation period, during which it was mostly a "decorative" animal, next to large luxury birds, and that only half a century later, it became an important part of the meals, until it even supplanted 
the royal birds. That is when it truly entered the poultry category. The last stage, quite recent, where turkeys replaced completely what used to be the ultimate luxury birds: capons.

From this point of view, turkeys offer a historically dated observation of the adoption of a domestic species from abroad by a new group of users. This notably allows us to reconstitute the decisions which have led to the incorporation of this species in a group of other domesticated species, a phenomenon that has occurred several times in the history in mankind, but in too ancient times for us to have any concrete ideas.

I have deliberately left out "Christmas turkeys" from this historical panorama (when did it become the required dish for this time of the year?), as well as the larger matter of its propagation to the rest of the world outside Europe. The European colonists who settled in New England took turkeys from Europe with them to supplant hunting birds and become essential for Thanks Giving. When did this happen? How did turkeys reach Asian countries? We know this beautiful Mughal miniature painting by Mansur which belonged to Emperor Janhangir, dated $1612^{138}$. And finally, turkeys are now birds that are the object of industrial farming imposing itself on the international market ${ }^{139}$, cut up or in elaborate products far from and much simpler than how they appeared in the European cookbooks of the past centuries. Now everybody has access to turkey meat, it has become ordinary.

All these questions would require new developments: "and this is a different story..."

Figure 19: « Dindon bridé pour relevé » (trussed turkey), in Le livre de cuisine by Jules Gouffé (7th edition, $1888: 563$ )

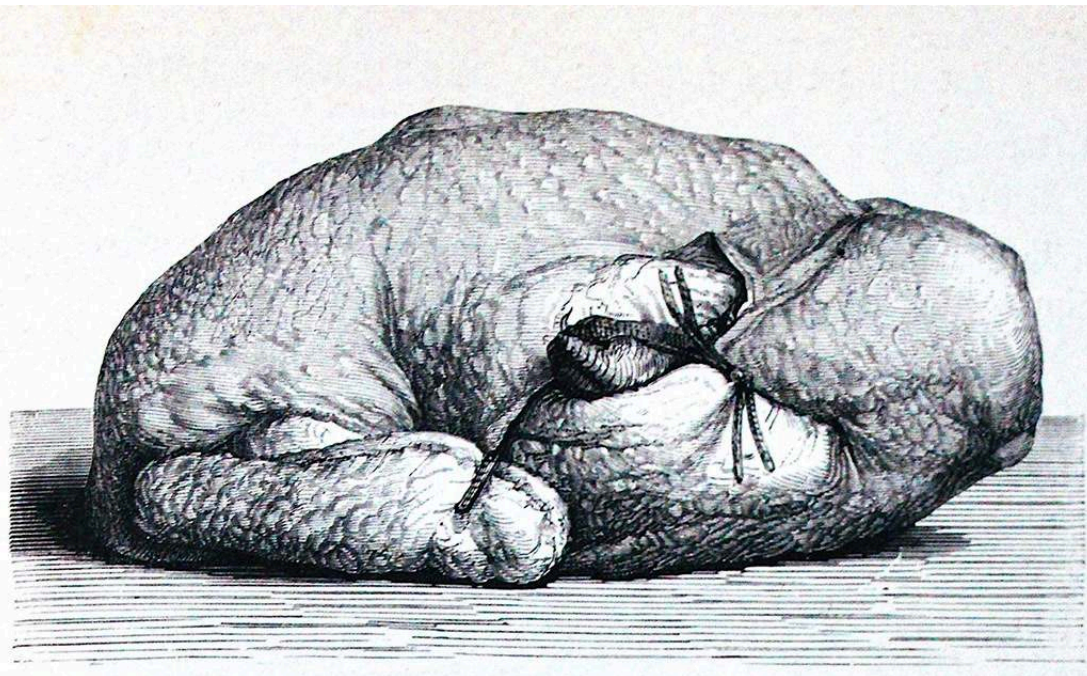

Fig. 120. Dindon bridé pour relevé.

ACKNOWLEDGEMENT : I thank archaeozoologists Eduardo Corona and Aurélie Manin, who encouraged me to write this paper, and more specifically Aurélie, for whom history of turkey has no more secrets, for the comments she was kind enough to share. I also thank my sister Sylvie Bahuchet for her help in the translations of Italian recipes. 


\section{BIBLIOGRAPHY}

\section{Original documents}

Many ancient books were consulted thanks to several websites making available facsimile of original editions : Gallica https://gallica.bnf.fr/, Biblioteca nacional de España http:// www.bne.es/, Biblioteca nacional de Portugal http://www.bnportugal.gov.pt/, as well as https:// books.google.fr/, Internet Archive https://archive.org/ and for English cookbooks http:// www.foodsofengland.co.uk/references.htm

References for cookbooks are quoted in Annex.

Aldrovandi Ulyssis 1600 - Ornithologiae tomus alter (Liber XIII). Bologne, Bellagamba.

Barcía Carballido y Zúñiga A. G. de (ed.) 1749 - La historia de D. Fernando Colón en la qual se da particular, y verdadera relacion de la vida de el Almirante D. Christoval Colón. In : Historiadores primitivos de las Indias Occidentales, vol. I. Madrid.

Belon, Pierre, 1555 - De l'histoire de la nature des oiseaux, avec leurs descriptions et naïfs portraicts Paris, Cuellat.

Buchoz, 1777 - Traité économique et physique des oiseaux de basse-cour, Liège, Desoer.

Buffon, Georges L. de, 1771 - Histoire naturelle des oiseaux. Tome second. Paris, Imprimerie royale.

Cardelli, Pierre, 1826 - Manuel du cuisinier et de la cuisinière, à l'usage de la ville et de la campagne. $4^{\mathrm{e}}$ éd., Paris, Manuel Roret.

Chomel, Noël, 1741 - Dictionnaire Economique. Commercy, Thomas.

de Acosta, Joseph, 1590 - Historia natural y moral de las Indias. Sevilla, Juan de Leon. Trad. fr. 1598 par Robert Regnault, Histoire naturelle et morale des Indes. Paris, Orry.

de Oviedo, Gonzalo Fernandez, 1526 - Somario de la natural y general historia de las Indias. Toledo, Valdes.

Diderot, Denis \& Jean le Rond d'Alembert (éds.), 1751 - Encyclopédie, ou dictionnaire raisonné des sciences, des arts et des métiers. Tome IV. Paris, Briasson et al.

Du Chesne, Joseph, 1627 - Le pourtraict de la santé. Paris, Morel.

Dugdale, William, 1666 - Origines Juridiciales. London, Warren.

Estienne, Charles, 1565 - L'agriculture et maison rustique. Lyon, Martin.

Gallo, Agostino, 1565 - Dieci giornate della vera agricoltura, e piaceri della villa. Venetia, Farri.

Gessner, Conrad, 1553 - Icones avium omnium. Zurich, Froschover.

Gessner, Conrad, 1555 - Historiae animalium Liber III qui est de Avium natura. Zurich, Froschover.

Heresbach, Conrad, 1573 - Rei Rusticae Libri quatuor. Colonia, Birckmann.

Johnston, Jan, 1657 - Historiae naturalis de avibus libri VI. Amsterdam, Schipperi

La Mare, Nicolas de, 1710 - Traité de la police. Tome II, Cot, Paris, pp. 649-1496 [« Poule d'Inde » p. 1377] 
Le Choyselat, Prudent, 1569 - Discours oeconomique. Paris, Chesneau.

Le thrésor de santé ou ménage de la vie humaine,1607 - Lyon, Huguetan.

Le Grand d'Aussy Pierre Jean-Baptiste, 1782 - Histoire de la vie privée des français. Pierres, Paris, 373 p.

Lemery, Louis, 1705 - Traité des aliments. $2^{\mathrm{e}}$ éd., Paris, Witte.

Li tre trattati di Messer Mattia Giegher, 1639 - Padova, Frambotto.

Liger, Louis, 1700 - Oeconomie générale de la campagne, ou nouvelle maison rustique. Paris, de Sercy.

Linocier, Geofroy, 1583 - L'histoire des plantes. Paris, Macé

Mémoire statistique du département de l'Indre, par le $C^{\text {te }}$ d'Alphonse, préfet ; Paris, Imprimerie Nationale, an XII [1803-1804]

Núñez de Coria, Francisco, 1572 - Aviso de sanidad que trata de todos los generos de alimentos. Madrid, Cusin.

Núñez de Coria, Francisco, 1585 - Regimiento y aviso de sanitad. Medina del Campo, Landry.

Odolant-Desnos P. J. 1787 - Mémoires historiques sur la ville d'Alençon et sur ses seigneurs; Tome second. Malassis le Jeune, Alençon, 640 p.

Pisanelli, Baldassare, 1583 - Trattato della natura de cibi e del bere. Roma, Bonfadino.

Rabelais, François, 1542 - La vie treshorrifique du Grand Gargantua (Livre 1). Lyon, Juste.

Rabelais, François, 1548 - Le Quart Livre, des faictz et dictz heroiques du noble Pantagruel. Lyon, Pierre de Tours.

Savonarola, Michel \& Bartolomeo Boldo, 1576 - Libro della natura e virtù delle cose che nutriscono. Venetia, Guerra.

Tanara, Vincenzo, 1644 - Economia del cittadino in villa. Bologna, Dozza.

Tanara, Vincenzo, 1674 - Economia del cittadino in villa. Venetia, Curti.

Zanon, Antonio, 1763 - Lettere sull' agricoltura, le arti e il commercio, vol. I. Venezia, Fenzo.

\section{Dictionaries}

Alberti de Villeneuve François d' 1796 - Nouveau dictionnaire françois-italien. Venise, Bassan.

Antonini Annibal 1752 - Dictionnaire italien, latin et français. Lyon, Duplain.

Bluteau Raphael 1728 - Vocabulario portuguez e latino. Coimbra, Companhia de Jesu.

Canal Pierre 1603 - Dictionnaire français-italien. Genève, Chouet.

Cotgrave Randle 1611 - A dictionarie of the French and English tongues. London, Islip.

de Covarrubias Sebastián 1611 - Tesoro de la lengua castellana. Madrid, Sanchez.

de las Casas Cristóbal 1570 - Vocabolario de las dos lenguas toscana y castellana. Sevilla, Aguilar.

de Moraes Silva Antonio 1789 - Diccionario da lingua portugueza. Lisboa, Lacerdina.

de Nebrija Antonio 1495 - Dictionarium latinohispanicum, et vice versa. Antverp, Steelfij.

Dictionnaire universel françois et latin vulgairement appelé dictionnaire de Trévoux 1738-1742 -

Nancy, Pierre Antoine. 
Düez Nathanaël 1678 - Dictionnaire italien et français. Genève, de Tournes.

Féraud Abbé 1787 - Dictionnaire critique de la langue française, Tome I : A-D. Marseille, Mossy.

Furetière Antoine 1690 - Dictionnaire universel. La Haye, Leers.

Minsheu John 1617 - A Dictionnary in Spanish and English. London, Brown.

Oudin Caesar 1627 - Thresor des trois langues, espagnole, françoise, et italienne. Genève, Crespin.

Oudin Caesar 1675 - Thresor des deux langues françoise et espagnolle. Lyon, Bourlier.

Percival Richard 1591 - Bibliotheca hispanica: Containing a grammar, with a Dictionarie in Spanish and English, and Latine. London, Iackscon.

Real Academia Española 1737 - Diccionario de la lengua castellana. Madrid, del Hierro

Société typographique 1829 - Vocabolario universale italiano. Napoli, Tramater.

\section{Modern documents}

Allard J. 1988 - La cuisine espagnole au Siècle d'Or. Mélanges de la Casa de Velásquez 24 : 177-190.

Bahuchet S. 2017 - Les jardiniers de la nature. Paris, Odile Jacob, 400 p.

Barcía Carballido y Zúñiga A. G. de (Ed.) 1749 - La historia de D. Fernando Colón en la qual se da particular, y verdadera relacion de la vida de el Almirante D. Christoval Colón. In : Historiadores primitivos de las Indias Occidentales, vol. I. Madrid.

Boudier V. 2009 - Appropriation et représentation des animaux du Nouveau Monde chez deux artistes nord italiens de la fin du XVIe siècle. Le cas du dindon. Food and History 7 (1) : 79-101.

Bouquet F. (Ed.) 1883 - La Parthénie, ou Banquet des palinods de Rouen en 1546 : poème latin du XVI siècle par Baptiste Le Chandelier (avec une introduction et des notes). Rouen, Société des Bibliophiles normands, CLXXXV + $151 \mathrm{p}$.

Braga I.D. 2006 - Influências estrangeiras nos livros de cozinha portugueses (séculos XVI-XIX). Alguns problemas de Análise. In : Estudos em Homenagem ao Prof. Doutor José Marques, vol. 2. Porto, Faculdade de Letras : 237-247.

Bray W. 1993 - Crop plants and cannibals: Early European impressions of the New World. Proceedings of the British Academy 81 : 289-326.

Brillat-Savarin J.A. 1854 (1825) - Physiology of taste, or Meditations on transcendental gastronomy, Translated by F. Robinson. Philadelphie, Lindsay \& Blakiston, $347 \mathrm{p}$.

Capatti A. \& Montanari M. 2002 - La cuisine italienne. Histoire d'une culture. Paris, Seuil, 430 p.

Cimber L. \& Danjou F. 1835 - Archives curieuses de l'histoire de France. $1^{\text {re }}$ série, Tome 3. Paris, Ed. Beauvais.

Coron S. (Ed.) 2001 - Livres en bouche. Cinq siècles d'art culinaire français. Paris, Hermann, éditeurs des sciences et des arts / Bibliothèque nationale de France, 251 p.

Couperie P. 1964 - L'alimentation au XVII e siècle : les marchés de pourvoierie. Annales. Economies, sociétés, civilisations 19 (3) : 467-479.

Dartigue C. 1937 - Traité passé par Henri D'Albret pour alimenter sa maison (1538). Annales du Midi : revue archéologique, historique et philologique de la France méridionale 49 (196) : 409-418. 
De Grossi Mazzorin J. \& Epifani I. 2016 - Introduzione e diffusione in Italia di animali esotici dal Nuovo Mondo: il caso del tacchino (Meleagris gallopavo L.). L'Idomeneo 2015 (20) : 55-74.

Eiche S. 2004 - Presenting the Turkey: the fabulous story of a flamboyant and flavourful bird. Florence, Centro Di, $127 \mathrm{p}$.

Estorach S. \& Lequenne M. (Ed.) 2002 - Christophe Colomb, la découverte de l'Amérique Paris,. La Découverte/Poche, $352+434 \mathrm{p}$.

Faugeron F. 2016 - Le luxe alimentaire à Venise à la fin du Moyen Âge et au début de l'époque moderne : entre lois somptuaires et fastes dogaux. Mélanges de l'École française de Rome-Antiquité [En ligne], 128-1. URL : http://journals.openedition.org.inshs.bib.cnrs.fr/mefra/3264

Flandrin J.-L. 1992 - Le dindon sur les tables européennes 16ème-18ème siècles. Ethnozootechnie $49: 71-84$.

Flandrin J.-L. 1996 - L'alimentation paysanne en économie de subsistance. In : Flandrin J.-L. \& Montanari M. (Ed.) Histoire de l'alimentation. Paris, Fayard : 597-627.

Flandrin J.-L. 2002 - L'ordre des mets. Paris, Odile Jacob, 278 p.

Flandrin J.-L., Hyman P. \& Hyman M. 1983 - La cuisine dans la littérature de colportage. In : Le cuisinier françois, textes présentés par J.-L. Flandrin, P. et M. Hyman. Paris, Montalba :11-107. (Bibliothèque Bleue).

Frere C.F. (Ed.) 1913 - A proper new book of cookerye. Cambridge, Heffer, clxiv + 124 p.

Gaffarel P. (Ed. \& trad.) 1907 - De orbe novo de Pierre Martyr Anghiera. Les Huit Décades traduites du latin, avec notes et commentaires. Paris, Leroux, $755 \mathrm{p}$.

Gauvin B. (Ed.) 2003 - Pietro Martire d'Anghiera, De Orbo Novo Decades ; « Décades du Nouveau monde. I, La décade océane », suivi du "Quatrième voyage de Christophe Colomb ». Paris, Les Belles lettres, XCVII+374 p.

Geoffroy Saint-Hilaire I. 1986 (1861) - Acclimatation et domestication des animaux utiles. Reéd. facsimilé Paris, La maison rustique/Flammarion, $536 \mathrm{p}$.

Gomes J. P. 2016 - Cozinhar « á Portugeza » com Lucas Rigaud. Identidade alimentar portuguesa no Cozinheiro Moderno. Revista de História da sociedade e da cultura. 16 : 243-270.

Hyman P. \& Hyman M. 1996 - Imprimer la cuisine : les livres de cuisine en France entre le XV et le XIX ${ }^{\mathrm{e}}$ siècle. In : Flandrin J.-L. \& Montanari M. (Ed.) Histoire de l'alimentation. Paris, Fayard : 643-655.

Larousse P. 1870 - Grand dictionnaire universel du XIX siècle, Tome 6:D. Paris, Admin. du grand dictionnaire, $1470 \mathrm{p}$.

Laurioux B. 1988 - Entre savoir et pratiques : le livre de cuisine à la fin du Moyen Âge. Médiévales. $14: 59-71$.

Lehmann G. 1999 - Le livre de cuisine en Angleterre aux XVII ${ }^{e}$ et XVIII ${ }^{e}$ siècles : par qui, pour qui ? XVII-XVIII. Bulletin de la société d'études anglo-américaines des XVII et XVIII siècles. 48: 89-102.

MacNutt F.A. (Ed.) 1912 - De Orbe Novo. The Eight Decades of Peter Martyr D'Anghera. Translated from the Latin with Notes and Introduction. Putnam, New York, 2 volumes, $414+448$ p.

Manin A. 2015 - Aspects matériels et symboliques de l'utilisation des animaux dans le nord de la Mésoamérique, entre le Classique et la Conquête (200-1521 ap. J.-C.). Archéologie et Préhistoire. Thèse, Muséum national d'Histoire naturelle, 656 p. 
Manin A., Corona-M.E., Alexander M., Craig A., Thornton E.K., Yang D.Y., Richards M. \& Speller C.F. 2018 - Diversity of management strategies in Mesoamerican turkeys: archaeological, isotopic and genetic evidence. Royal Society open science 5 (1) : 171613.

Orlandi A. 2011 - « Io hebbi il gallo et l'hebbi a caro ». Cenni sulla introduzione e la diffusione del tacchino. Rivista di Storia dell'Agricoltura, Accademia dei Georgofili, LI (1) : 75-84.

Peyrebonne N. (Ed.) 2011 - Le livre de cuisine de Roberto de Nola. Paris, Classiques Garnier, 330 p. Plouvier L. 1995 - Introduction de la dinde en Europe. Scientiarium Historia 21 (1) : 13-34.

Poplin F. 1992 - Panorama du dindon du Nouveau Monde à l'Ancien. Sa place dans notre bestiaire. Ethnozootechnie 49 : 1-14.

Redondo Buey P. 2014 - El arte de cozina de Diego Granado (1599), primer libro de cocina en lengua castellana. Universidad de Valladolid. Facultad de Medicina, $50 \mathrm{p}$.

Robillard de Beaurepaire E. 1892 - Le journal du sire de Gouberville, publié sur la copie du manuscrit original faite par l'abbé Tollemer. Avec une introduction et un appendice. Mémoire de la Société des antiquaires de Normandie, Caen, vol. XXXI, 385 p.

Schorger A.W. 1966 - The wild turkey. Its history and domestication. Norman, University of Oklahoma Press, $625 \mathrm{p}$.

Serres O. de 1996(1600) - Le théâtre d'agriculture et mesnage des champs. Arles, Actes Sud, 1545 p. Simon Palmer C. 1977 - Bibliografía de la gastronomía española. Madrid, Ed. Velazquez, 324 p.

Wright A.H. 1914 - Early Records of the Wild Turkey. The Auk 31 (3) : 334-358.

\section{APPENDIXES}

\section{Consulted cook books}

Spanish books

\begin{tabular}{|c|c|c}
\hline Year & Title (town of printing and publisher) & N. recipes \\
\hline 1542 & Lobera de Avila Vergel de sanidad (Alcala, de Brocar) & 0 \\
\hline 1572 & Núñez de Coria Aviso de sanidad (Madrid, Cusin) & 0 \\
\hline 1607 & Hernandez de Maceras Libro del Arte de Cozina (Salamanca, Ramirez) & 2 \\
\hline 1611 & Martinez Motiño Arte de cozina (Madrid, Sanchez) & 4 \\
\hline 1614 & Granado Libro del arte de cozina (Lerida, Manescal) & 6 \\
\hline 1758 & Altamiras Arte de cocina (Barcelona, de Bezères) & 2 \\
\hline 1822 & D. A. P. Z. G. La nueva cocinera (Madrid, Alvarez) & 3 \\
\hline 1828 & Manual del cocinero (Madrid, Amarita) & 9 \\
\hline 1845 & Novisimo arte de cocina (Madrid, Boix) & 1 \\
\hline 1898 & Brecarelli Manual de la cocinera española y americana (Madrid, Escribano) & 5 \\
\hline
\end{tabular}

Italian books 


\begin{tabular}{|c|c|c}
\hline Year & Title (town of printing and publisher) & N. recipes \\
\hline 1549 & Christoforo di Messisbugo Banchetti (Ferrara, Bughlat \& Hucher) & 0 \\
\hline 1560 & Domenico Romoli La singolar dottrina (Venetia, Tramezzino) & 4 \\
\hline 1570 & Bartolomeo Scappi Cvoco secreto (Venetia, Tramezzino) & 31 \\
\hline 1587 & D. Romoli La singolare dottrina (Venetia, Farri) & 5 \\
\hline 1593 & Vincenzio Cervio Il trinciante (Roma, Sabbia) & 8 \\
\hline 1627 & Vittorio Lancellotti Lo scalco pratico (Roma, Corbelletti) & 20 \\
\hline 1662 & Ottavio Stefani L'arte di ben cucinare (Mantova, Osanna) & 11 \\
\hline 1773 & II cuoco galante [Vincenzo Corrado] (Napoli, Raimondi) & 15 \\
\hline
\end{tabular}

\section{French books}

\begin{tabular}{|c|c|c}
\hline Year & Title (town of printing and publisher) & N. recipes \\
\hline 1555 & Livre fort excellent de cuysine (Lyon, Arnouillet) & 0 \\
\hline 1604 & Lancelot de Casteau Ouverture de cuisine (Liège, Streel) & 4 \\
\hline 1651 & La Varenne Le cuisinier françois (Paris, David) & 9 \\
\hline 1656 & Pierre de Lune Le cuisinier (Paris, David) & 15 \\
\hline 1661 & Le Cuisinier methodique (Paris, Promé) & 3 \\
\hline 1662 & Pierre de Lune Le nouveau et parfait maistre d'Hostel royal (Paris, Loyson) & 18 \\
\hline 1662 & L'escole parfaicte des officiers de bouche (Paris, Ribou) & 5 \\
\hline 1693 & L.S.R. L'art de bien traiter (Lyon, Bachelu) & 5 \\
\hline 1705 & Massialot Le cuisinier roïal et bourgeois (Paris, Prudhomme) & 20 \\
\hline 1735 & La Chapelle Le cuisinier moderne (La Haye, de Groot) & 54 \\
\hline 1739 & Les dons de Comus ou les délices de la table [François Marin] (Paris, Prault) & 74 \\
\hline 1739 & Menon Nouveau traité de cuisine (Paris, Paulus-du-Mesnil) & 42 \\
\hline 1741 & La Chapelle Le nouveau cuisinier royal (Paris, Prudhomme) & 51 \\
\hline 1746 & Menon La cuisinière bourgeoise (Paris, Guillyn) & 25 \\
\hline 1775 & Menon La cuisinière bourgeoise (Bruxelles, Foppens) & 28 \\
\hline 1806 & Viard Le cuisinier impérial (Paris, Barba) & 12 \\
\hline 1817 & Viard Le cuisinier royal (Paris, Barba) & 15 \\
\hline 1826 & Cardelli Manuel du cuisinier (Paris, Roret) & 19 \\
\hline
\end{tabular}

\section{English books}

\begin{tabular}{|l|r|c}
\hline Year & Title (town of printing and publisher) & N. recipes \\
\hline 1584 & A.W. A book of cookrye (London, Allde) & 2 \\
\hline 1587 & Thomas Dawson THE good husvvifes levvell (London, Wolfe) & 1 \\
\hline 1594 & The good Huswifes Handmaide for the Kitchin (London, Jones) & 2 \\
\hline 1615 & Gervase Markham The English Hus-wife (London, Jackson) & 4 \\
\hline 1615 & John Murrell New book of cookerie (London, Brownie) & 1 \\
\hline 1658 & The Compleat Cook (London, E. B.) & 0 \\
\hline 1658 & Theodore Mayenne Archimagirus Anglogallicus (London, Bedel \& Collins) & 1 \\
\hline 1660 & Robert May The accomplisht cook (London, Brooke) & 7 \\
\hline 1664 & Hannah Wolley The cooks guide (London, Dring) & 1 \\
\hline 1673 & Cookery dissected [William Rabisha] (London, Calvert) & 7 \\
\hline 1708 & Henry Howard The England newest way of all sorts of cookery (London, Coningsby) & 3 \\
\hline 1714 & A Collection of Above Three Hundred Receipts (London, Wilkin) & 1 \\
\hline 1725 & Robert Smith Court Cookery: Or The Complete English Cook (London, Wotton) & 6 \\
\hline 1725 & John Nott The Cooks and Confectioners Dictionary (London, H. P.) & 8 \\
\hline 1737 & Eliza Smith The Compleat Housewife (London, Pemberton) & 4 \\
\hline 1739 & Sarah Harrison The House keeper's Pocket book (London, Ware) & 10 \\
\hline 1747 & The art of cookery by a Lady [Hannah Glasse] (London, the author) & 3 \\
\hline 1755 & Elizabeth Cleland A new and easy method of cookery (Edinburgh, Gordon et al.) & 15 \\
\hline 1769 & Elizabeth Raffald Experienced housekeeper (Manchester, Harrep) & 6 \\
\hline 1802 & John Mollard The Art of Cookery Made Easy and Refined (London, Nunn) & 7 \\
\hline
\end{tabular}


Portuguese books

\begin{tabular}{|c|c|c}
\hline Year & Title (town of printing and publisher) & N. recipes \\
\hline 1680 & Domingos Rodrigues Arte de cozinha (Lisboa, Galvaõ) & 25 \\
\hline 1780 & Lucas Rigaud Cozinheiro modern (Lisboa, Ameno) & 32 \\
\hline 1849 & Cozinheiro complete (Lisboa, Correia da Cunha) & 14 \\
\hline 1840 & R. C. M. Cozinheiro imperial (Rio de Janeiro, Laemmert)) & 50 \\
\hline
\end{tabular}

\section{NOTES}

2. . "Lettre de Christobal Colon, vice-roi et amiral des Indes, aux Très Chrétiens et Très puissants Roi et reine d'Espagne..., fait aux Indes, en l'île de la Janahica, le 7 juillet de l'année 1503 »; ed. Estorach \& Lequenne 2002, p. 362.

3. «Gallinas muy grandes y la pluma como lana vide hartas. »; trad. R. H. Major. Italian text: « vedetti galline molto grandi, che le piume loro erano come lana... » (Lettera rarissima, 1505).

4. Peter Martyr d'Anghiera, Pietro Martire d'Anghiera or Pedro Mártir de Angliera (1457-1526), of Italian birth, was attached to the court of the Catholic Kings of Spain and then assigned to the Council of the Indies. He dedicated himself to becoming the historian of the discovery, by directly collecting testimonies from the discoverers of America, while transcribing the official documents and manuscripts, from which he wrote letters to the Roman Catholic hierarchy (including the popes). These letters were gathered and published by himself in the eight "Decades of the New World" (De Orbe Novo Decades, from 1494 to 1526).

5. "[...] inter quas pro altilibus habent eas quas pauonibus feminis colore ac magnitudine similes esse, gustu etiam et sapore diximus aliquando.» [IV, § 5]. This text was translated in French by Gaffarel (1907) : "Quant aux oiseaux, ils engraissent ceux dont nous avons parlé, et qui ressemblent à des paons femelles pour la couleur, la grandeur, le goût et la saveur. » (1907 : 258) and later by B. Gauvin: « Ce lieu abrite [divers animaux] ainsi que des oiseaux variés parmi lesquels ils élèvent, en guise de volailles, ceux qui ressemblent à des paonnes par la couleur, la taille, le goût et la saveur comme nous l'avons dit plusieurs fois. » $(2003: 238)$.

6. . « [...] 200. cargados de varias suertes de bastimentos, con Gallinas de la Tierra, que son mejores que las nuestras [...]", in : La historia de D. Fernando Colón en la qual se da particular, y verdadera relacion de la vida de el Almirante D. Christoval Colón..., Madrid, 1749, vol. I : 106.

7. "Les femmes élèvent à la maison des oies et des canards comme les femmes de chez nous. Des paons vivent dans les bois - mais ils ne sont pas ornés ni multicolores car le mâle differe peu de la femelle (...)» "Nos hommes passèrent là quelques jours dans l'abondance: en effet on remettait quatre aiguilles ou épingles à celui qui ramenait un paon (...) " (Première décade, livre 8 ; éd. Gauvin 2003, pp. 172, 174). It shall be considered that these birds could have been another wild species, Meleagris ocellata, endemic from Yucatan and Guatemala.

8. « Les nôtres rapportèrent de cette région de très beaux cercopithèques et plusieurs perroquets de toutes les couleurs. » (p. 178); « certaines grosses comme des noisettes »

9. Yañez Pinzon and his brother made a first voyage towards the coast of central America in January 1500 , but it seems that there is no mention of farmed birds in the account reported by Martyr ( $1^{\text {st }}$ decade, chapter 9$)$.

10. In 1555, Richard Even translated and interpreted this text very differently, a translation quoted by Wright (1914: 344) : “(...) a great multitude of theyr peacocks, both cockes and hennes, deade and alive, as well to satisfie theyr present necessitie, and also to cary with theym into Spayne for increase." (Even 1555, p. 79). Gaffarel translated in similar terms as MacNut, that is to say without mentioning Spain: "Ils donnèrent, en plus de l'or et de l'encens, des paons qu'on ne rencontre que chez eux; ils different sensiblement des nôtres par la variété des couleurs. Les femelles 
étaient vivantes, car on les réservait pour la propagation de l'espèce : quant aux mâles, ils en donnèrent un grand nombre, mais pour les manger sur-le-champ. » (1907:198).

11. "Ay unos pavos ruvios y otros negros y la colas tienenlas dela hechura a delas pavas de España/ pero en el plumaje y color: los unos son todos ruvios y la barriga cõ un poco del pecho blãco y los otros tienen sobre la cabeça una hermosa cresta o penacho d plumas bermejas el q es bermejo : y negras el es negro: $y$ son de mejor comer que los de España. Estos pavos son salvajes y algunos ay domesticos en las casas que los toman pequeños. Los vallesteros matan muchos dellos porque los ay en mucha cantidad. (...)» (Pavos, Cap. xxxvij)

12. Recent archaeozoological studies seem to confirm this hypothesis (Manin et al. 2018).

13. "La carne destos pavos es muy buena y sin comparaciõ mejor y mas tierna que la delos pavos de España.»

14. Il gallo, e la gallina d'India son molto più grossi di corpo che non è il pauone nostrale, e il gallo fa la ruota ancor egli come il pauone nostrale, e ha le piume negre, e bianche, \& il collo cesputo di pelle, \& il capo la testa un corno di carne, ilqual quando il gallo si corruccia, gonfia, \& vien grosso in modo che li cuopra tutto il mostaccio,(...) e nella punta d'esso petto ha una pannocchia di setole a modo di quelle del porco congiunté nelle piume, e ha la carne molto piu bianca, e piu molle del pauone nostrale, e si frol la piu presto che il cappone, e altri simili uolatili.

15. . « De gallo peregrino : Is quem ex novo orbe deportatum vidi (...)»; « Illius quem vidi (...)» (Gessner 424-425; cf. aussi Plouvier : 16).

16. Guineafowl (Numida meleagris, Numididae) is a domesticated bird of African origin.

17. Ornithologiae tomus alter (Liber XIII), 1600 : De Gallopavone (pp. 35-44); engraving of a male (Gallopavo mas cum oryza, p. 39) and a female (Gallina Indica, p. 40). It is known that Aldrovandi ordered a drawing of a turkey for the collection of illustrations for his Cabinet (Bray $1993: 305$ ).

18. This engraving was also used in the posthumous book Monstrorum historia (1642, p. 324).

19. . " mil autres différentes espèces d'oiseaux et d'animaux de forêt qui jamais n'ont été connues ni de figure ni de nom, et desquelles il n'est fait aucune mention soit entre les Latins soit entre les Grecs... » (trad. fr. 1598 par Robert Regnault, Livre IV ch. XXXVI, p. 195).

20. Minsheu resumed and completed Percival's dictionary (1591); hence introducing a new meaning.

21. In his book Il cuoco segreto, Bartolomeo Scappi notes (cap. 141) : ... « il Gallo \& la Gallina d'India, liquali in alcuni lochi d'Italia si dimandano pauoni d'India » (1570, p. 61)

22. "...questo animale non hà per ancor determinato certo nome; chi lo chiama Gallo d'India, chi Pauone Gallo, chi Gallo Pauone, chi Gallinazzio, e da'Rustici è chiamato Tocco [...] "

23. « TACCHINO. Specie di uccello gallinaceo che ha la testa rossa e cerulea, e sparsa di alcuni peli. [...]; altrimenti Pollino, Pollo d'India ; e più generalmente Gallo d'India, Gallonaccio. [...] Tacchino diff. da Pollo d'India. Pollo d'India è della lingua nobile italiana, e Tacchino è della toscana. »

24. Livre I, chapitre XXXVII ; Livre IV, chapitres LI et LIX

25. «...poules d'Inde, qui sont de très grosses poules venuës de l'Amérique... »

26. «Dinde: Coq d'Inde. On appelle ainsi quelquefois la poule d'Inde. Dindon: coq d'Inde.»

27. «Dinde : On apèle ainsi quelquefois une poule d'inde. Dindon, Coq-d'inde. »

28. "Gros oiseau de basse cour dont la chair est très estimée ». «La femelle du dindon, appelée autrement Poule d'Inde. ».

29. «Perû. Ave domestica (...), em Italia lhe chamão, Gallo Indiano, \& Gallo d'India; em França Coqdinde; em Castella Pavo, ou Gallo de las Indias. (...) Gallus Indicus. »

30. «PERÙ : Ave de penna, vulgar, e caseira. O vûlgo affectadamente diz perum : chamase Perú, por virem do Perú, e a principio se chamarão Gallinhas do Perú. »

31. This word is not in Robert Cawdrey 1604 A Table Alphabetical.

32. Cf. Gessner 1553: "Italice: Gallo d'India. Gallice : Coc d'Inde. German : Ein Indianischer oder Kalekuttischer Han. Angli: a kok of Inde».

33. Schorger (1966 : 464) quoting Cárcer y Disdier (1960) on the archives of the Indies. 
34. "Real Cédula a Miguel de Pasamonte, tesorero general de Indias, para que envíe en cada navío de los que vengan, 10 pavos, mitad machos y mitad hembras, de los que se crían en La Española que se llevaron de Tierra Firme, y haga que los entreguen en la Casa de Contratación de Sevilla donde los tendrán para lo que les mande.» (Archivo General de Indias, INDIFERENTE,418,L.3,F.182V). See picture: http:// pares.mcu.es/ParesBusquedas20/catalogo/show/246126

35. This requirement is intended to Spaniards in West Indies, where turkeys were present and raised. This letter does not prove that it was the case in Europe (A. Manin, comm. pers.).

36. For the state of the art on domestication and raising of turkey in Mexico until the conquest, see Manin 2015.

37. See how Pierre Martyr described Tenochtitlan («Temistitan »): "Their domestic animals are geese and ducks, and they also keep a number of peacocks, which we call hens, and which they rear as our housekeepers do their chickens. I have already somewhere said that these animals resemble our pea-hens in size and the colour of their plumage (...)" (5 $5^{\text {th }}$ decad, chapter 3, tr. MacNutt 1912: 109). "Les indigènes élèvent aussi dans leurs maisons une quantité de paons, que nous appelons des poules. Ils les élèvent comme nos ménagères font pour les poulets. J'ai déjà dit quelque part que ces animaux ressemblaient à nos paons femelles pour la grosseur et la couleur des plumes $(. .$.$) » \left(5^{\mathrm{e}}\right.$ décade, chapitre 3, trad. Gaffarel 1907 : 448-449).

38. For this section and the next one, I am basing myself on the sources indicated by Schorger 1966, Flandrin 1992, Eiche 2004, but also on Le Grand D'Aussy 1782, and even the Grand dictionnaire by Pierre Larousse 1870, sources which I have all consulted as often as possible.

39. This episode occurred long before the testimony quoted by Tanara (1644: 217), according to whom the first Galli d'India spotted in Bologna had been sent to Genoa as a gift to the Lords Boncompagni at the time of the death of Pope Gregory XIII (in 1585):

40. «Indicarum, ut vocãt, avium recens apud nos usus \& educatio: Nam ante annum redemptionis tricesimum supra sesqui millesimum apud nos non sunt visae, neque veteribus arbitror notas, tamet si non desint qui existiment inter Melegrides (...) » (p. 290)

41. « in gallo opus naturae mirabile apparer »

42. Marguerite of Angoulême (1492-1549), Francis I's older sister, was the wife of Henri II of Navarre (1503-1555); their daughter Jeanne d'Albret (1528-1572) will be the mother of Henri IV.

43. "On assigna à Pierre Beauchêne, parquier du château, 31 livres 8 sols 6 deniers par chacun an, pour l'entretien \& la nourriture de six coqs \& poules dindes de la princesse de Navarre qui se rendois au Plessislez-Tours. » (Odolant-Desnos 1787 : 567-568).

44. "Le mercredi XXVIIe, jour Sct-Jehan (...). Au matin, avant que je fusse levé, ung serviteur de Malin Lucas, de Scte-Croyx, à la Hague, m'apporta ung coq et une poule d'Inde. Je luy donné IIII s. ; il disna céans (...).» (Robillard de Beaurepaire $1892: 541$ )

45. «Chez nous on en faisait le plus grand cas; \& on l'estimait même assez pour être offert aux Rois comme un don digne d'eux. Lorsque Charles IX passa par Amiens en 1566, parmi les présens que le Corps-de-ville vint mettre à ses pieds, il y eut douze dindons. ".

46. $1^{\mathrm{er}}$ service (des entrées) : "Gallina indica. Dimisso orbe tuo, nostris dum finibus erras, / Venisti, infaustis cursibus, ut caderes. Alliud. Gallinae in speciem me tellus barbara misit, / Sic notus vobis Indicus orbis erit. » («Les convives connaîtront le continent indien, cette terre barbare, qui a produit la Poule d'Inde. »). $2^{\mathrm{e}}$ service (des rôtis) : «Pulli indici. Inter aves cicures, si quis, me indice, certet, / Palmam (nec dubium est) Indica casta feret. » (" Poulets d'Inde. Parmi les oiseaux apprivoisés, si le débat était porté devant moi, la palme (ce n'est pas douteux) appartiendrait à la caste de l'Inde. »). French Translation by Bouquet.

47. This is the purchasing account for this banquet, in which were served «soixante-six pouletz dinde, à 20 sols pièce." and "Sept cocqs dinde pour faite trente cinq pastez, au faict de 30 sols pièce."; they were purchased to " Jehan Langlois et Blaise de Sallesbrusse, marchans rôtisseurs demourans à Paris ». Almost 1400 pieces of meat, from pidgeon to pork, were purchased to these roast cooks. At «maistre paticier Pierre Moreau, dit Bridon », were payed 6 livres "pour la façon de quarante 
pastez de coq-dinde ». (Cimber \& Danjou 1835 pp. 417-419). Flandrin (1992 : 71) gives a comparison of the prices of the various poultries ordered for this banquet.

48. "Turkies 2 , rated at $4^{\mathrm{s}}$ a piece, by Mr. Walpole ; (...) Turky-chicks 4 , rated at $4^{\mathrm{s}}$ a piece, jointly by Mr Morgan and Mr Catlyn"- par comparaison, une grue ou un cygne valent $10^{s}$, un chapon $2^{s}$ 6." (Dugdale 1666, ch. 48, p. 135).

49. This event is frequently mentioned, for example in Le grand dictionnaire (Larousse 1870, s.v. dindon) or Wright (1914), but I was not able to find a specific document about the menu, or even the location where the banquet took place.

50. Pasticci di Galli d'India in forma di Aquila

51. Pallanchotte d'India arrosto, lardate minutamente, servite con pane di Spagna

52. Constitutio Thomae Cranmeri Archiepiscopo, \& aliorum fratrum suorum, dans John Leland De rebus Britannicis collectanea (1774:38).

53. A sumptuary law had previously been promulgated in 1547 by the Venetian Senate, forbidding the selling and public presentation of pheasants, peafowls, turkeys, francolins and galli selvatici (forest cocks) (quoted by De Grossi Mazzorin \& Epifani 2015: 59)

54. Décret du Conseil de Venise du 22 mars 1557 : De'Conviti Cap. XI : «(...) sia proibito dar fagiani, cotorni, francolini, galli selvatici, pavoni nostrani. E parimenti non si possano in detti Conviti metter in tavola pernici, e galli, che chiamamo d'India, se non in questo modo: cioè che ad elezione di chi farà il Convito nel numero delle due vivande arroste, come nel seguente Capitolo, si possan dare galli d'India, o pernici; ma non sia per modo alcuno lecito porre in tavola in un istesso Convito galli d'India, e pernici insieme, e separatamente. » (Zanon 1763 Lettere sull' agricoltura, le arti e il commercio, vol. I, p. 32).

55. "At the time of the Regulation, the Turkey Fowles were not yet very common, nor in large numbers, to be sold in the Markets, or by the Roasters. This Regulation contains a very wide enumeration of all the different species of Poultry \& Game, which were then in the Trade, \& fixes the price." [«lors du Reglement qui fut fait (...) les Poules d'Indes n'y étoient pas encore bien communes, ni en assez grand nombre, pour être venduës dans les Marchez, ou par les Rotisseurs. Ce Reglement contient un denombrement fort ample de toutes les diferentes especes de Volailles \& de Gibier, qui etoient alos dans le Commerce, \& en fixe le prix. (...) »]

56. Analysing the price of the poultry ordered for the banquet of Catherine de' Medici in 1549, Flandrin noticed that the turkeys are less expensive than other luxury birds (turkey cocks 30 sols, turkey hens 20 sols), and suggested that they "were not so rare anymore." (Flandrin 1992: 71). Actually, the game is the most expansive meat (pheasants, bustards, cranes, 70 to 80 sols); farmed birds are either of comparable prices (peafowls 40 sols) or completely prohibitively expensive and hence very rare (swans 100 sols).

57. "...cette viande est auiourd'huy si commune en France, que les bassecours des bonnes maisons, les granges \& mestairies des vilageois en sont pleines. »

58. «Le Coq d'Inde est un oiseau assez connu, \& d'un aussi grand usage parmi les aliments que le Chapon \& le Poulet (...)»

59. ... i galli, e le galline d'India cuoprono una parte delle nostre campagne, sono divenute il cibo de Contadini, della plebe; mortificano i prezzi delle carni bovine, e de vitelli, e fanno un commercio attivo, colla Dominante.

60. «signe, sigonne, houtarde, grue, pan, faisant »

61. [...] E benche costino assai nell'alleuarli; nondimeno, per essere delicati da mangiare, stà bene a tenerne, e massimamente ogni persona nobile, per honorarsi con gli amici, quando i maschi sono ben grassi, come alle uolte ne ho donati, e morti, che giungeuano a trenta, e trenta cinque libre l'uno; avenga che le femine sono apena la mitade, lequali covano i loro ovi d'ogni tempo, \& ogn'una sedici, fin diciotto. [...]

62. Mai non ho voluto tener di questi uccelli; parte perche muoiono facilmente, mentre sono piccioli; \& parte anco, perche sono sporchi, dishonesti, \& horridi da vedere por cõto della lora gresta [...] 
63. Poi nati i polli, siano tenuti per un mese in luogo non freddo, e non lasciati andar fuori, fin che non sono ben coperti di piuma, o che faccia caldo, non mancando a pascerli di diverse herbe dell' horto cotte, di pane e di ricotta.

64. "Celuy qui nous apporta cest oyseau en France, soit que nous l'appellons coq, ou paon d'Inde, nous a plustost enrichy de gueule, que de profit, car c'est un droit coffre à avoine, un gouffre de mangeaille, où l'on ne peut prendre autre plaisir que de bruit \& fureur, quant aux grands : ou d'un continuel piollement, quant aux petits. Vray est que la chair en est delicate, mais fade \& de dure digestion : c'est pourquoy lon la fait saupoudrer, \& fort larder \& aromatizer. Il y a trop plus de plaisir \& de bonté de chair au Paon. " (Chapitre 15, p. 68). In all successive editions $(1572,1583,1658 \ldots)$, precisions were added: «outre que l'un \& l'autre sont sales, \& hideux à voir, à cause de leur difformité de teste: car le masle n'a point de crestes eslevées comme nos coqs : mais au lieu de creste a une carnosité rouge, \& sous le menton un palais gros \& long qui s'enfle, \& est tendu de diverse couleur quand il entre en furie. " (1658, Chapitre 20, p. 83).

65. "Et afin de ne faire plus lõgs propos, advise à colloquer ta somme en achapt de poulles, nõ Meleagrides, que Belon en sa peregrinatiõ a voulu dire estre noz poulles Indiennes, qui sont vrays greniers à avoyne, mais des poulles comunes du pays, \& y negocie par la forme cy apres escrite: Et ne sois si impatient que tu n'attende le periode." ( $\left.f^{\circ} 6 \mathrm{~V}^{\circ}\right)$ (Discours oeconomique 1569, reproduced without changes in the subsequent editions).

66. «La commodité qu'on tire de la poulaille d'Inde, à cause de l'abondance des precieuses chairs, dont elle honore la table du seigneur en toutes saisons, \& les ceufs de mesnage qu'elle donne en certain temps de l'annee; font surpasser les difficultés de son esleuement \& nourriture, sous lesquelles on fouloit gouuerner ce bestail, lors que premierement il vint à nostre cognoissance. Croiant que parce qu'il est estranger, ne pourroit viure \& se multiplier de par deçà, qu'auec extreme souci \& despense. Mais le temps maistre des arts, nous a enseigné ces oiseaux-ci, estre de passable entretien, sans excessif coust, s'esleuer presques en tout aer, bien-que le chaud lui soit le plus propre \& agreable, cõme le plus approchant de son naturel, \& se cõseruer auec moderee solicitude.»

67. "(...) pourmener par la campagne, trouvant beaucoup de mangeaille, des racines, de la vermine, des herbes, des grains des fruits sauvages dont \& pour-néant elles se paissent très-bien ».

68. "Qvant à l'engraisser, cela nest necessaire par traictement particulier: dautant que par l'ordinaire nourriture \& conduite, ceste poulaille se maintient tous-jours en poinct d'estre mangee. "

69. "C'est une chose bien avantageuse pour le ménage, de voir sa basse-court garnie de Poulets \& de Poules d'Inde. Ces animaux rendent beaucoup de profit; \& quelque peine qu'on puisse prendre à les élever, on ne doit point en avoir regret; le plaisir d'en joüir de quelque manière qu'il nous plaît, nous dédommage aisément des soins qu'ils nous ont coûté.» (p. 73)

70. "Le matin, si-tôt que le Soleil est levé on fait partir ce petit Dindonnier, auquel on recommande fortement de ne point abandonner son troupeau, \& de le conduire tantôt d'un côté, \& tantôt de l'autre, afin que la diversité des pâturages réveille l'appetit de ces animaux, \& les fasse crôtre au plûtôt. (...) Le soir venu, ce Dindonnier conduira ses Dindes devant luy, pour les mettre dans leur Poulailler : mais avant que de les y renfermer, il observera soigneusement de leur jetter un peu de grain, pour leur faire prendre des forces. La Mere de Famille ne manquera point aussi de faire tous les soirs la revîë de ses Dindes, \& de les compter, afin que le conducteur veille beaucoup sur elles, \& n'en laisse point égarer. » (p. 77).

71. "valet chargé de mener paitre les dindons \& les dindes. On ne mene ces volailles aux champs, que quelque tems après le soleil levé. On les remene dans la basse-cour sur les dix heures, où elles restent jusqu'à midi qu'elles retournent aux pâturages pour jusqu'au soir. »

72. hò veduto condurne due centenaia di questi dal Regno di Napoli a Roma, con suoi piedi, per camino di cento miglia. (ed. 1651, p. 217)

73. « La sua polpa è doppia \& treppia, \& simimente difficile da digerire. » (1576:124)

74. "Vray est que leur chair est tendre \& delicate, neanmoins elle engendre un gros suc, se digere malaisément, \& abonde en viscositez, parquoy il est bon de les saupoudrer \& aromatizer. » (p. 204) 
75. « C'est une friande, excellente, bonne et saine viande, de facile digestion, de tres-bonne nourriture, engendrant quantité de bon sang \& de semence: bref c'est une viande des meilleures, plus saines \& delicieuses qui se trouvent. » (p. 423).

76. Quando (...) la Gallina d'India sono uecchie, sarà la carne loro buona nel maggior freddo dell'anno. Et $i$ pollastri loro nascendo di Marzo, sarã buoni d'Agosto, ; \& Settembre, perche uogliono esser di quattro mesi almeno, ma le femine, cioè pollanche uorranno hauer dell'una, et dell'altra cinque o sei mesi, \& quelle saranno eccelentissime.

77. « La stagione più propria di questi animali e delli mesi di Giugno, Luglio, \& Agosto riuscendo in questi tempi delicati, per essere piccoli, e teneri, vengono molto apprezzati nelle tavole de'Signori grandi. »

78. Granado (1614) repeats the exact same recommendations: «En el invierno despues de muerto el gallo o gallina de la India, la dexaras sin sacar las tripas quatro dias, y en el verano dos ».

79. "Piglisi la pollancha giovane morta d'une giorno l'Estate, \& L'Invernata di tre, perche tal volatice presto si frolla, \& ha la carne assai piu bianca (...)"

80. La vera stagion del Gallo, e gallina d'India è la più fredda parte dell'anno, ed essendo essi di carne molto dura, è ben lasciarli per alquanti giorni star morti, accioche divengan frolli. Dei Galli, e galline giovani d'India non accaderebbe quasi far quì mentione, poiche ordinariamente non se n'ammazzano nel nostro paese; ma pure, se alcuno avesse gusto di mangiarne, sappia, che i maschi vogliono essere almen di quatro mesi, e le femmine, o pollanche di cinque, o sei. (1639: 5)

81. "Les meilleurs Coqs d'Inde, pour le goût \& pour la santé sont ceux qui sont jeunes, gras, \& qui ont été nourris avec un grand soin. (...) Cependant quand il est un peu trop vieux, sa chair est dure, coriasse, \& difficile à digerer. " (Lémery $1705: 295)$.

82. «Le Dindon vieux se met en pâte \& à la daube. Le Dindon jeune, ou le Dindonneau, fournit davantage à la cuisine, ou se diversifie davantage. »

83. "Nous autres, aujourd'hui, nous en trouvons la chair dure \& séche. Nous ne mangeons rôti que le dindonneau. Pour le dindon, on ne le sert guères qu'en daube ou en pâté; à moins qu'il ne soit farci de truffes, comme ceux qui nous arrivent du Périgord. »

84. Laurioux was able to show how the printed versions of Le Viandier in the $15^{\text {th }}$ century were different from the manuscripts that had been spreading since the $14^{\text {th }}$ century (1988: 62).

85. About the history of cookbooks, see Braga 2006, Flandrin et al. 1983, Hyman 1996, Laurioux 1988, Lehmann 1999. On french cookbooks, see the catalogue of the exposition in Bibliothèque de l'Arsenal Livres en bouche (Coron 2001).

86. See French edition and comments (Peyrebonne 2011).

87. King of Naples from 1458 to 1494.

88. Cortar de las aves, y primeramente del pavo; Salsa de pavo especias; Para hazer salsa de pavo; Emborroçamiento de pavos o capones.

89. This paragraph ends with comments about the quality of the flesh: «(...) son tenidos sus pollos crecidos acerca de los cortesanos, por gustosos y tiernos, pero quieren estar manidos de tres dias en inuierno. Los viejos son duros de digestiõ, y los nuevos no faciles: porque tienen mucha superfluydad: cuestan mucho su criança."

90. "Ay tambien vn genero de gallinas de la india que llaman pauos en España, porq casi son de su grandeza, $y$ tienen diuersos colores en sus plumas. » (fol. $\left.115 \mathrm{~V}^{\circ}-116\right)$

91. Cutting and seasoning (Corte del pavo; Como se ha de adereçar vn pauo).

92. Roasting, one gravy, empanadas (- de menudos, - en masa blanca).

93. Roasting (Pabos asados, pabo asado con verdure).

94. Cutting, stuffing, roasting, pies pasteles, and dumplings albondiguillas.

95. The terminology that is used is quite ambiguous because he switches from specifics to global recipes, for example: ways to cut "birds, and first of all pavos" (corte de las aves, y primeramente del pavo, p. $9 \mathrm{~V}^{\circ}$ ) but below, about the capon: «...se quiere cortar, asi como el pauon, ò capon (...) aunque algunos hazen alguna diferencia en el corte del pauo al del capon, y de la gallina(...)». 
Similarly p. 12 «emborraçamiento de pavos, o capones». Et p. $47 \mathrm{~V}^{\circ}$ " para assar el gallo y la gallina de las Indias ».

96. This book separates recipes for pabo, from that for pabipollo and pabipolla, names for the young turkeys. Recipes: Despojos de pabo á la aldeana, Pabo en adobo, Pabo á la provenzana, Pabipolla al asador.

97. Pavo relleno asado.

98. Pavo asado, Pavo relleno, Despojos de pavo, Alones, Alones con habichelas.

99. Among others (roast, marinade), Alones fritos, - a lo marinero, - mechados; pavo asado con criadillas, picadillo de pavo.

100. Manuel du cuisinier et de la cuisinière, à l'usage de la ville et de la campagne by P. Cardelli, $4^{\text {th }}$ ed., Roret 1826.

101. Christoforo di Messisbugo died in 1548. As the intendant of the House of Este (in Ferrare), he gives many innovating recipes and is considered the inventor of stuffed pasta dishes (tortelloni).

102. Furono questi uccelli cõdotti di Numidia, e non d'India [...]. Sono detti da Greci Meleagrides [...]

103. Among others: Pollanche d'India stuffate con presciuto, piselli, \& agresto [verjuice], \& savor di verzure; pollanche d'India infagianate con salsa di visciole; galline d'India arroste, e allesse, in più modi; at which he added in 1587 pollanche d'India infagiante (sic) configo di milangoliforti, zuccaro, cannella, et garofani.

104. Il trinciante mentionned twice porcelletti d'India.

105. Names and descriptions of some dishes : Polli d'India arostiti ripieni d'hortolani \& coperti di sparagi grossi cotti nel butiro; Pollanche d'India allessate coperte di ravioli verdi senza sfoglia; Galli d'India ripieni d'uccelletti, \& cervellati, \& tartufi, arostiti con caperini sopra, \& melangoli ; Polanche d'India allessate coperte du cardi, cervellati e formaggio; Pollanche d'India a modo d'Aquile, coperte de gielo, e fior de pignioli sopra; Galline d'India grosse, arrostite, armate di stecchi con prugnoli, \& ortolani sopra; Polanche d'India arosto, due per piatto adornate di pasta sfogliata.

106. Bartolomeo Scappi (v. 1500-1577).

107. This seems to be the first book to do so (and it will be reproduced in Spanish by Granado in 1614) - if not the only one.

108. A few examples of the names of Scappi's dishes: Pollanche d'India ripiene di prugnoli arrostite allo spedo servite con sugo di melangole [bigarades], \& zuccaro sopra; Galline d'India arrostite allo spedo, servite fredde con limoncelli, \& zuccaro sopra; Pollanche grosse d'India alessate, servite con fiori di borragine, \& petrosemolo sopra; Pollanche d'India alessate, servite con cardi cotti, \& cervellate spolverizzate di cascio [cheese], zuccaro, \& cannella; Galli d'India ripieni d'ogliapotrida alla Spagnola, arrostiti allo spedo, serviti con capperini ; \& zuccaro sopra, trinciati.

109. Lancellotti was Cardinal Aldobrandino's butler, Camerlengo of the pope in Rome.

110. A few examples to illustrate the variety and beauty of the titles: pasticci di Galli d'India in forma di Aquila...; Starne arrosto (...) con sei nidi pieni di piccatiglio di petto di Galli d'India arrosto, stufato con medolla... ; Galli d'India arrosto, poi lardato di lardoni di cedra condito... ; Galli d'India bolliti, coperti di papardelle alla Romana, con zuccaro, e cannella sopra; Pollanchotte d'India arrosto, lardate, servite con sfogliatelle tonde, ripiene di bianco magnare...

111. . Le coscie [thighs] si possono mettere alla gradella [small grill], bagnate cõ aceto rosato, butiro overo oglio di Toscana, o d'altra qualità, purche sia buono.

112. Gallinaci, o Galli d'India assagianati, regalati con osselloni alla Milanese, tramezati cõ lumache empite, fatte di pasta di marzapane, servite sopra con una salsa di capparini, e sopra un copertore di pasta sfogliata.

113. Vincenzo Corrado (1736-1836).

114. Some names of dishes : Tacchina lessa ; in Gello per Entremets; All'Arlechina ; Farsita al Butirro ; Farsita alli Finocchi; Alla Contadina ; In Fricassea ; in Arrosto alla Contadina ; in arrosto all'Apiciana; Alla Beccaccina; In Galantina; Petti di Tacchina in Fricondò; Al Latte; Coscie di Tacchina Farsite; Al Salpicon.

115. About the history and the evolution of Italian cuisine, see Capatti \& Montanari (2002). 
116. Potage de dindonneaux, Ragoust de poulets d'inde à l'Espagnol, Poulets d'inde desossez et farcy, and various Rostis à la broche.

117. "Daube is a stew served cold, \& is very popular these days" as Massialot explains (" La daube est un ragoust qui se mange froid, \& qui est fort en usage aujourd'hui »). To do so, the meat is larded and seasoned with "salt, pepper, cloves, nutmeg, bay leaf, spring onions, lime"

118. The flesh is cut into very thin filets, cooked in a pan with a slice of ham, oil, parsley, spring onions, mushrooms, and the mix is chopped finely in successive layers.

119. Not only are there types of preparations, and not recipes per se, in the chapter Dindons et dindonneaux: roasted on a spit, boned into blanquette, with bechamel sauce, in stew, in a pan, in fricandeau, in galantine, in ballon, in daube ("with a quarter gallon a white wine"), rolled, in bread, in brézolles, "à la bourgeoise", the wing tips "in several diversified ways", in fricassee, with onion, in matelote, with Champagne wine, "in terrine with green mash"...

120. "Le Dindon vieux se met en pâte \& à la daube. Le Dindon jeune, ou le Dindonneau, fournit davantage à la cuisine, ou se diversifie davantage. Le corps se met à la broche \& fait du rot: pour entrée on le met à l'échalotte, en filet entier aux trufes, en galantines, roulé aux huîtres, \& aux cornichons. Les ailes \& 1 'estomach se mangent glacés dans leur jus (...) "

121. This is boned meat, which is first half-roasted or half-boiled, and then boiled in a dish on ember.

122. The turkey-cock needs to be "as fat as possible".

123. A pye, a-la-daube, a pot, to stew; sauce for boiled Turkey

124. A pye, a sallad magundy (from a roasted turkey with anchovies and oisters) and two gravies.

125. Carbonado (roasted, cut with its skin, sautéed with butter, spices, breadcrumbs and anchovies), a sallet (cooked meat, seasoned with herbs, nutmeg, pepper, grated horseradish...), and an odd to congeal (a type of preserve where the boned and boiled meat is placed in a jar in alternating layers with spices, onions, horseradish, bacon, anchovies, filled with white wine, sealed and cooked in bain-marie for $6 \mathrm{~h}$; once it is cold, you break the jar and serve with many spices).

126. Roast, Pies (with one in the French way), Carbonado, To souse, a ragoo, stuffed turkey with herbs, turkey with onion essence.

127. To boil with Oysters, a la daube, Turkey pie, to souse, and a salamongundy (minced turkey meat and a little bit of chicken - the type of cooking is not specified; to be served with minced meat mixed with hard-boiled eggs, anchovies, capers, mushrooms, lemon zests, herbs - sorrel, chive, spinach -, sprinkled with orange and lemon juice, oil and vinegar).

128. Besides the 3 types of roasting (with or without larding), with the stuffing and the 5 types of sauces to accompany, the stew, H. Glasse gives several versions of the salamongundy, including one for various Fowls (cold minced Fowl meat with herring, cucumber, apples, onion, pickled red cabbage, boiled parsley, celery, hard-boiled eggs - with the whites separated from the yolks -, all ingredients thinly minced, which can be mixed or arranged separately; to be served with lemon slices and flowers placed around).

129. Roasted or boiled Turkey or fowles with celery, in a pie; a fricasey (a cream sauce browned with eggs to accompany the boiled poultry), a ragoo of livers (the livers are browned in a pan with broth, butter, flour, salt, pepper, oysters and ketchup).

130. To roast, to boil, to hash (boning, cutting the meat, then boiling in a pan with broth and lemon during "6 or 7 minutes"), souced Turkey, a stewed with celery sauce, and 2 sauces for roasted or boiled turkey.

131. Next to the roasts with various types of stuffing (including one with truffles and chestnuts) and their sauces, the broths with various arrangements, pâtés, you find similar recipes with different names: Pulled Turkey looks like Cleland's ragoo (and Mollard compares it to benshamelle); on the other hand, his ragout is different (the turkey is boiled and chopped, but the sauce contains artichokes, boiled cocks' crests, white mushrooms, (hard-boiled?) eggs, benshamelle, salt, 
lemon juice and Cayenne pepper. He describes "Grills and sauce, which are generally eaten after dinner" (small grilled pieces, with a coulis and various sauces).

132. Notice the various written forms of these dishes: salamongundy, solomongondy, sallad magundy, and sallet.

133. Perum salchichado, almondegas de perum, perum de sopa branca, perum com salsa real, perum estilado, empadas de perum sem osso.

134. Some names of dishes: potagem a Franceza (with liver, mustard, bacon, studded onions, pepper, nutmeg, cardamom, lemon juice), perum Mourisco, peruas assadas sobre sopa de nata, perum em gigote de toucinho (bacon) e vinho branco com substancia de vitella, pratinhos de pasteis saboianos de peito (breast) de perum...

135. Perú a crema, e assado para uma entrada, peitos de perús para uma entrada, perú assado á italiana para uma entrada.

136. Sopa de assado, manjar branco amarello, perna armada, gallinha (or perú) em pé, recheada (stuffed), empadas (pâté), alerões de vario modo. Dishes in the menus: Perú com salsa real, salchichado, estufado, assado com prezunto (ham).

137. This book was a great success and was republished until 1887. As far as turkeys are concerned at least, the recipes of the successive editions are similar.

138. Kept in the Victoria and Albert Museum collections (London), $n^{\circ}$ IM.135-1921; url: http:// collections.vam.ac.uk/item/017088/painting-mansur/.

139. 500 millions of turkeys are farmed each year worldwide...

\section{ABSTRACTS}

This paper considers the conditions and consequences of the discovery of the turkey Meleagris gallopavo L. (Phasianideae). I try to define how this new animal will be inserted into the European languages, through terminology, into the scientific knowledge, and into uses and practices, planning to specify steps of its acceptance into the European food corpus. For this inquiry, I analyze chronologically successive written evidences, i. e. archives discovered by historians, as well as books (about cooking, agriculture) and dictionaries, in order to underline the steps of the adoption of the turkey in our European civilization (Spain, Italy, France and England).

\section{INDEX}

Keywords: turkey, Europe, history, discovery, introduction, husbandry, food and foodways, cooking

\section{AUTHORS}

\section{SERGE BAHUCHET}

Professeur Muséum national d'Histoire naturelle, Paris 